Research Article

\title{
Mechanical Responses to Different Excavation Methods of Qichongcun Tunnel in Guiyang City, China
}

\author{
Siwei Xie $(\mathbb{D}$, Feng Huang $(\mathbb{D}$, Guihe Wang $(\mathbb{D}$, Chaoyang Zhu, Yunji Su, and Feng Qian \\ School of Engineering and Technology, China University of Geosciences (Beijing), 100083 Beijing, China \\ Correspondence should be addressed to Feng Huang; huangfeng@cugb.edu.cn
}

Received 17 June 2021; Accepted 7 August 2021; Published 13 August 2021

Academic Editor: Zhengyang Song

Copyright () 2021 Siwei Xie et al. This is an open access article distributed under the Creative Commons Attribution License, which permits unrestricted use, distribution, and reproduction in any medium, provided the original work is properly cited.

\begin{abstract}
The construction method of tunnel has a critical impact on the stress and strain field during excavation. This study simulated the construction of Qichongcun tunnel by applying a different excavation method, including double-sided method, single-sided method, and three-step dynamic balance excavation method. The distribution and variation of the stress, vertical displacement, horizontal displacement of surrounding rocks, and stress of initial and secondary lining were studied. The results showed that large displacement of surrounding rocks would be induced during the construction in three-step method, but the stress of the second lining was small after completion of the construction. The displacement and stress of the three-step dynamic balance excavation method were larger than those of the other two methods, but it still met the requirements of safety.
\end{abstract}

\section{Introduction}

Karst is common geological condition in southwest China. There are karst cracks and cavities developed in the surrounding rocks of the tunnel. On one hand, karst water results in decrease of the strength of the surrounding rocks. On the other hand, the karst caves change the physical and mechanical properties of the surrounding rocks, which also leads to the changes of stiffness and stress field of the tunnel [1-3]. With the development of transportation infrastructure in China, more and more tunnel projects meet the complicated karst geological conditions [4]. The potential geological disasters have great influence on the tunnel construction in karst areas [5]. Karst-related problems in tunnel areas will cause great disasters, including water inrush, mud gushing, and collapse if this geology condition is not handled properly [6-9]. During the process of executing tunnel projects, various engineering accidents will happen if the awareness of geological features is lacking [10]. In recent years, surface exploration methods have begun to explore the joint inversion theory with multiple types of geophysical information. Gallardo and Meju initially realized the joint inversion of two kinds of geophysical information $[11,12]$. Xin proposed a comprehensive advanced geological prediction method for karst fissure water and hazardous geological formations. Meanwhile, a system and process for comprehensive high-risk karst tunnel forecasting has been put forward [13]. Qin developed a magnetic resonance sounder for tunnels, which conducted advanced detection of water-rich geological structures that may cause tunnel disasters [14]. There have been studies on the stress characteristics of surrounding rocks and tunnel support structures in tunnels [15-19]. The often adopted research methods were theoretical analysis and numerical simulation [20, 21]. Adachsa concluded that surrounding rock pressure was affected by the tunnel construction method and surrounding rock deformation had an impact on stress distribution [22]. Sterpi considered the stability of surrounding rocks under strain softening through simulation [23]. Bian et al. established a theoretical model of the mechanical characteristics of the surrounding rocks of the karst cave-tunnel system and derived the analytical solutions of the stress and deformation of the surrounding rocks when a deep tunnel was excavated under the existing karst cave based on Schwarz alternating method [24]. The mechanical properties of tunnels were also studied by means of in situ monitoring and model experiment $[25,26]$. Li conducted large-scale geomechanical model tests and numerical simulations, revealing the failure 
behaviors of the section tunnel and the change of the stress of surrounding rocks under overload conditions [27].

In this paper, numerical simulation and in situ monitoring are carried out to analyze the mechanical responses of the tunnel and surrounding rocks during different excavation methods.

\section{Geological Conditions and Procedures of Different Excavation Methods}

This study focuses on the tunnel located in Guiyang City, the capital of Guizhou Province. The area is famous for karst formations. An overview of the tunnel and the typical geology condition are shown in Figures 1 and 2.

The stratum is mainly interbedded by dolomitic limestone and argillaceous limestone. There are 4 layers in total. As is shown in Figure 3, there are sandstone, dolomitic limestone, argillaceous limestone, and dolomitic limestone layers from the left to the right. The integrity of the rock mass is broken, soft, moderately weathered, or strongly weathered. Finite element numerical models are established to analyze the surrounding rocks and supporting structures of the shallow-buried largespan tunnel, the Qichongcun tunnel. The rock model adopts the Mohr-Coulomb approach based on elastoplastic theory. The supporting structures are simulated by structural elements. The size of the numerical calculation model is shown in Figure 3. The rocks, soil, and structural parameters are shown in Tables 1 and 2.

The model of the double-side guide pit method was divided into 42,885 units. The excavation process included 36 steps. The interval of each excavation step was $1 \mathrm{~m}$. The second lining construction interval was $10 \mathrm{~m}$. The specific calculation steps are listed in Table 3 . The model of the double-side guide pit method is shown in Figure 4 and the construction sketch of the double-side pilot pit method is shown in Figure 5.

The model of the single-side guide pit method was divided into 38,497 units. The excavation process included 26 steps. Every excavation step and initial lining construction interval was $1 \mathrm{~m}$. The construction distance of the secondary lining was $10 \mathrm{~m}$. The specific calculation steps are listed in Table 4 . The model of the single-side guide pit method is shown in Figure 6 and the construction sketch of the singleside guide pit method is shown in Figure 7.

The three-step calculation model was divided into 39,424 units. The excavation process included 14 excavation steps. Every excavation step and the initial lining construction interval was $1 \mathrm{~m}$, respectively. The construction distance of the secondary lining was $10 \mathrm{~m}$. The specific calculation steps are listed in Table 5.

The model of the three-step method is shown in Figure 8 and the construction sketch of the three-step method is shown in Figure 9.

\section{Results and Discussion}

3.1. Double-Side Guide Pit Method. Calculations for excavation with the double-side guide pit method were performed. The plastic area and stress distribution of

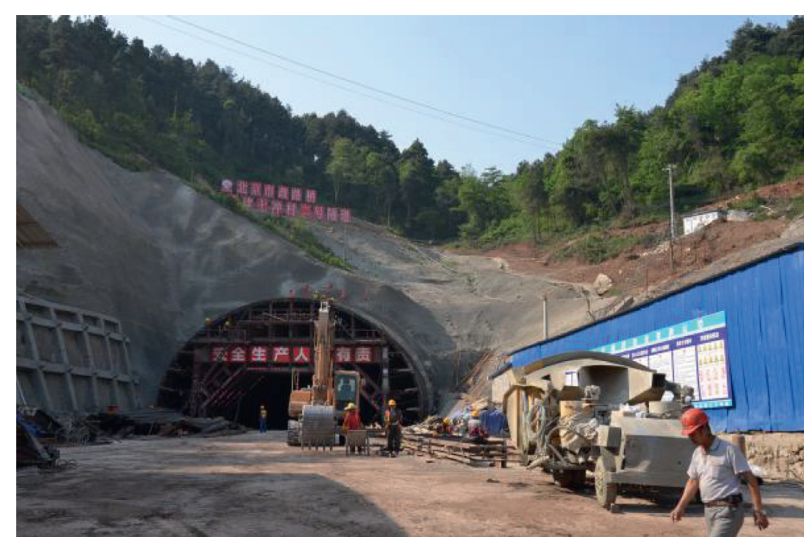

Figure 1: Overview of the tunnel.

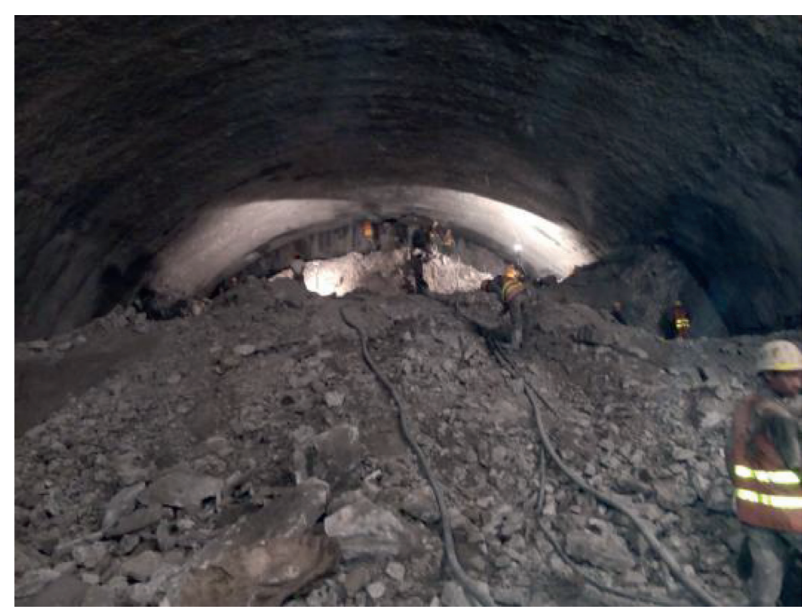

Figure 2: Typical geological conditions.

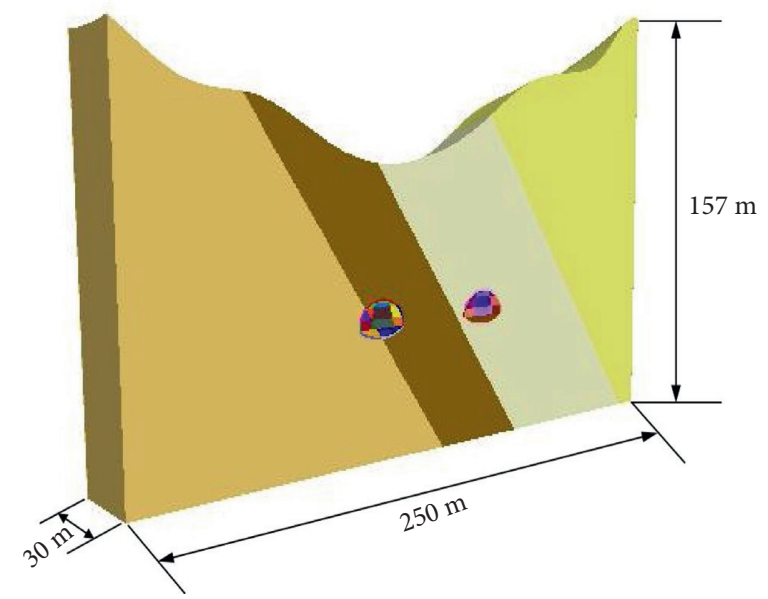

Figure 3: Numerical model.

surrounding rocks, vault displacement, and stress distribution of initial and second lining are shown in Figures 10-16.

The maximum principal stress of tunnel II is $0.947 \mathrm{MPa}$ during the construction using the double-side guide pit method. The maximum principal stress on the vault in 
TABLe 1: Geotechnical parameters.

\begin{tabular}{lccccc}
\hline Unit & Elastic modulus $(\mathrm{GPa})$ & Poisson's ratio & Cohesion $(\mathrm{kPa})$ & Friction angle $\left({ }^{\circ}\right)$ & Bulk density $\left(\mathrm{kN} / \mathrm{m}^{3}\right)$ \\
\hline Sandstone & 3.5 & 0.3 & 2,000 & 38 & 26 \\
Dolomite limestone & 2.5 & 0.2 & 1,200 & 35 & 26 \\
Argillaceous limestone & 1.5 & 0.25 & 500 & 35 & 25 \\
\hline
\end{tabular}

TABLE 2: Structural parameters.

\begin{tabular}{lccc}
\hline Component & Elastic modulus $(\mathrm{GPa})$ & Poisson's ratio & Bulk density $\left(\mathrm{kN} / \mathrm{m}^{3}\right)$ \\
\hline Initial lining & 20 & 0.2 & 24 \\
Second lining & 30 & 0.3 & 26 \\
Steel arch & 200 & 0.3 & 78.5 \\
\hline
\end{tabular}

TABLE 3: Main calculation steps for the construction of the double-side guide pit method.

\begin{tabular}{|c|c|}
\hline Calculation step & Construction conditions \\
\hline I.S. & Clear the displacement \\
\hline S1 & Excavate $1 \mathrm{~m}$ above the left guide pit \\
\hline S2 & Excavate $1 \mathrm{~m}$ above the left guide pit; make the first step of the steel arch and initial lining \\
\hline S3 & Excavate $1 \mathrm{~m}$ above the left guide pit; make the second step of the steel arch and initial lining \\
\hline S4 & Excavate $1 \mathrm{~m}$ above the left guide pit; make the third step of the steel arch and initial lining \\
\hline S5 & Excavate $1 \mathrm{~m}$ above the left guide pit; make the fourth step of the steel arch and initial lining \\
\hline S6 & Excavate $1 \mathrm{~m}$ above and below the left guide pit; make the fifth step of the steel arch and initial lining \\
\hline S7 & Excavate $1 \mathrm{~m}$ above and below the left guide pit; make the sixth step of the steel arch and initial lining \\
\hline S8 & Excavate $1 \mathrm{~m}$ above and below the left guide pit; make the seventh step of the steel arch and initial lining \\
\hline S9 & Excavate $1 \mathrm{~m}$ above and below the left guide pit; make the eighth step of the steel arch and initial lining \\
\hline S10 & Excavate $1 \mathrm{~m}$ above and below the left guide pit; make the ninth step of the steel arch and initial lining \\
\hline S11 & Excavate $1 \mathrm{~m}$ above the right guide pit; make the steel arch and initial lining of previous step \\
\hline$\ldots$ & \\
\hline S16 & Excavate $1 \mathrm{~m}$ below the right guide pit; make the steel arch and initial lining of previous step \\
\hline$\ldots$ & 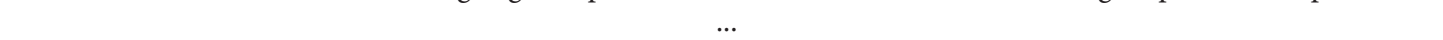 \\
\hline S21 & Excavate $1 \mathrm{~m}$ from middle and upper part of the tunnel; make the steel arch and initial lining of previous step \\
\hline$\ldots$ & 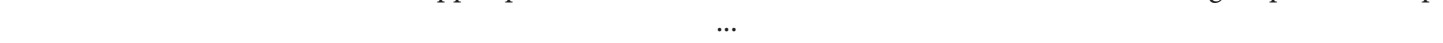 \\
\hline S26 & Excavate $1 \mathrm{~m}$ of the middle and lower part of the tunnel; make the steel arch and initial lining of previous step \\
\hline$\ldots$ & 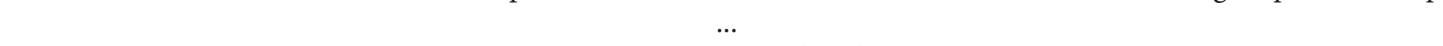 \\
\hline S36 & Excavate inverted arch \\
\hline S37 & Lay steel for inverted arch and pour inverted arch \\
\hline S38 & Second lining \\
\hline
\end{tabular}

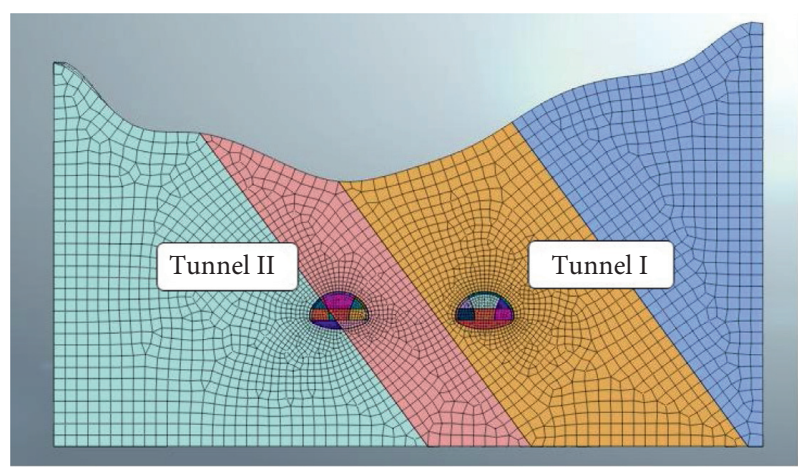

FIGURE 4: Model of the double-side guide pit method.

tunnel $\mathrm{I}$ is $0.645 \mathrm{MPa}$ and $3.6 \mathrm{MPa}$ at the arch foot. The maximum value of the small principal stress at the vault of tunnel II is $0.23 \mathrm{MPa}$ and $0.19 \mathrm{MPa}$ in tunnel I.

The maximum settlement of the vault of tunnel $\mathrm{I}$ is $11.7 \mathrm{~mm}$ in double-side guide pit method. The maximum

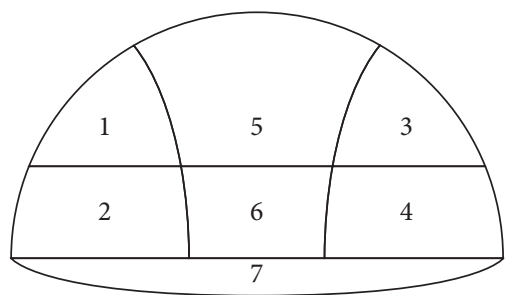

FIgURE 5: Construction sketch of the double-side guide pit method (1: the upper part of the left guide pit; 2 : the lower part of the left guide pit; 3: the upper part of the right guide pit; 4: the lower part of the right guide pit; 5 : the upper middle part; 6 : the lower middle part; 7: the inverted arch).

uplift at the bottom is $9.7 \mathrm{~mm}$ and the maximum settlement of the vault of tunnel II is $9.7 \mathrm{~mm}$, while the maximum uplift of the bottom of tunnel II is $8.1 \mathrm{~mm}$.

In tunnel I, the horizontal deformation of the left arch foot is $-0.8 \mathrm{~mm}$ and $1.1 \mathrm{~mm}$ of the right arch foot. In tunnel 
TABLE 4: Main calculation steps of single-side wall construction.

\begin{tabular}{|c|c|}
\hline Calculation step & Construction conditions \\
\hline I.S. & Clear the displacement \\
\hline S1 & Excavate $1 \mathrm{~m}$ of the tunnel guide pit \\
\hline S2 & Excavate $1 \mathrm{~m}$ of the tunnel guide pit; make the first step of the steel arch and initial lining \\
\hline S3 & Excavate $1 \mathrm{~m}$ of the tunnel guide pit; make the second step of the steel arch and initial lining \\
\hline S4 & Excavate $1 \mathrm{~m}$ of the tunnel guide pit; make the third step of the steel arch and initial lining \\
\hline S5 & Excavate $1 \mathrm{~m}$ of the tunnel guide pit; make the fourth step of the steel arch and initial lining \\
\hline S6 & Excavate $1 \mathrm{~m}$ of the tunnel guide pit; make the fifth step of the steel arch and initial lining \\
\hline S7 & Excavate $1 \mathrm{~m}$ of the tunnel guide pit; make the sixth step of the steel arch and initial lining \\
\hline S8 & Excavate $1 \mathrm{~m}$ of the tunnel guide pit; make the seventh step of the steel arch and initial lining \\
\hline S9 & Excavate $1 \mathrm{~m}$ of the tunnel guide pit; make the eighth step of the steel arch and initial lining \\
\hline S10 & Excavate $1 \mathrm{~m}$ of the tunnel guide pit; make the ninth step of the steel arch and initial lining \\
\hline S11 & Excavate $1 \mathrm{~m}$ of the first step of the main tunnel; make the tenth step of the steel arch and initial lining \\
\hline S12 & Excavate $1 \mathrm{~m}$ of the first step of the main tunnel; make the steel arch and initial lining of the previous step \\
\hline S13 & Excavate $1 \mathrm{~m}$ of the second step of the main tunnel; make the steel arch and initial lining of the previous step \\
\hline S14 & Make steel arch and initial lining of the previous step \\
\hline S15 & Excavate $1 \mathrm{~m}$ of the third step of the main tunnel; make steel arch and initial lining of the previous step \\
\hline$\ldots$ & ... \\
\hline S26 & Excavate inverted arch \\
\hline S27 & Lay steel for inverted arch \\
\hline S28 & Inverted arch \\
\hline S29 & Second lining \\
\hline
\end{tabular}

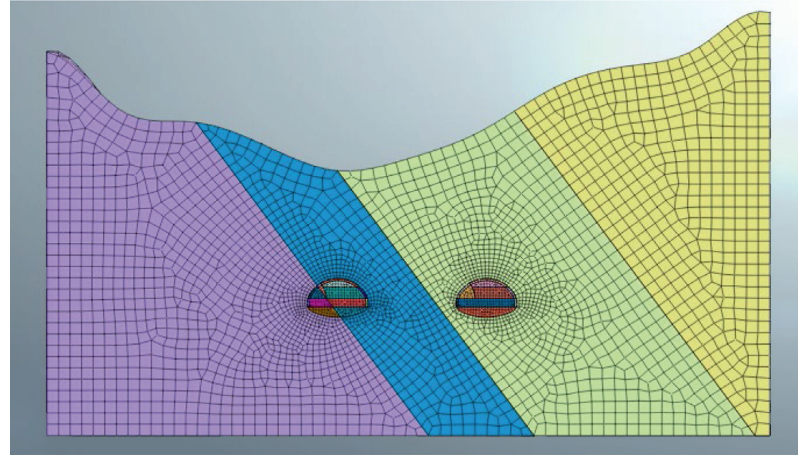

Figure 6: Model of the single-side guide pit method.

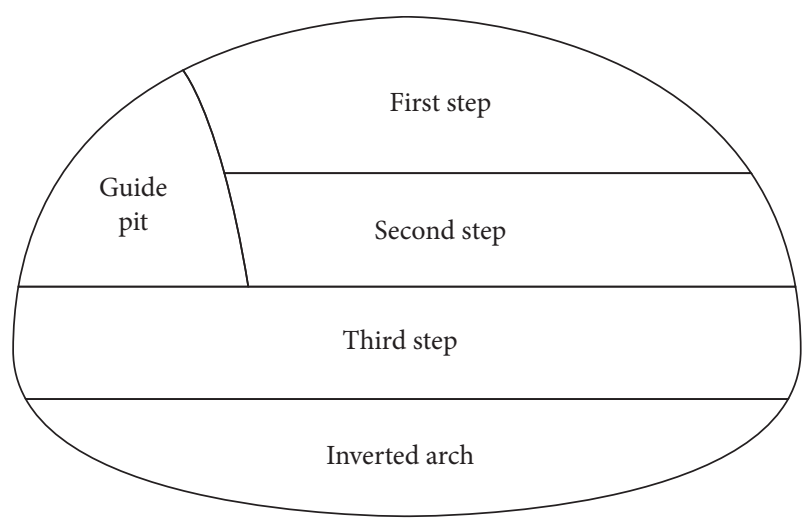

FIGURE 7: Construction sketch of the single-side guide pit method.

II, the horizontal deformation of the left arch foot is $-0.4 \mathrm{~mm}$ and $-0.8 \mathrm{~mm}$ of the right arch foot.

The stress is concentrated at the arch waist and arch feet in the double-side guide pit method, while the stress distribution is relatively uniform. The maximum concentrated stress is about $6.98 \mathrm{MPa}$.

The stress at the top of the second lining of tunnel II is about $0.92 \mathrm{MPa}$ and that at the arch foot is about $3.8 \mathrm{MPa}$ during construction with the double-side guide pit method. The stress at the top of the second lining of tunnel I is about $0.66 \mathrm{MPa}$ and $4.0 \mathrm{MPa}$ at the left arch foot.

3.2. Single-Side Guide Pit Method. Calculations for excavation with the single-side construction method were performed. The plastic area of surrounding rocks, stress distribution, vault displacement, and stress distribution of initial lining and second lining are shown in Figures 17-23.

The maximum principal stress of tunnel II is $0.838 \mathrm{MPa}$. The maximum principal stress at the vault of tunnel $\mathrm{I}$ is $0.543 \mathrm{MPa}$, while it is $4.03 \mathrm{MPa}$ at the arch foot. The maximum value of the small principal stress at the vault of tunnel II is $0.17 \mathrm{MPa}$ and $0.079 \mathrm{MPa}$ at the vault of tunnel I.

The maximum settlement of the vault of tunnel I is $15.3 \mathrm{~mm}$ after excavation, and the maximum uplift of the arch bottom is $11.5 \mathrm{~mm}$. The maximum settlement of the vault of tunnel II is $12.6 \mathrm{~mm}$ and the maximum uplift at the right arch bottom is $9.6 \mathrm{~mm}$.

The horizontal deformation at the left arch foot of tunnel I is $-1.5 \mathrm{~mm}$, while it is $2.4 \mathrm{~mm}$ at the right arch foot. The horizontal deformations of the surrounding rocks at left and right arch foot of tunnel II are $-0.9 \mathrm{~mm}$ and $-1.1 \mathrm{~mm}$, respectively.

The arch waist and arch foot in single-side guide pit method are subjected to large pressure. The stress concentration on the side wall is $6.2 \mathrm{MPa}$.

The stress at the top of the second lining of tunnel II is about $0.74 \mathrm{MPa}$ and the stress at the arch foot is about 3.6 MPa. The stress at the arch foot of tunnel $\mathrm{I}$ is about 4.4 $\mathrm{MPa}$, while it is $0.47 \mathrm{MPa}$ at the arch top. 
TABLE 5: Main calculation steps of the three-step method.

\begin{tabular}{|c|c|}
\hline Calculation step & Construction conditions \\
\hline I.S. & Clear the displacement \\
\hline S1 & Excavate the first $1 \mathrm{~m}$ of the tunnel for anchor and lining \\
\hline S2 & Excavate $1 \mathrm{~m}$ of the first step and the second step for the steel arch and lining \\
\hline S3 & The first step, the second, and third steps are $1 \mathrm{~m}$ each for anchor the steel arch and lining \\
\hline S4 & Excavate $1 \mathrm{~m}$ of the first, second, and third steps and make the steel arch and initial lining \\
\hline S5 & Repeat the previous step \\
\hline S6 & Repeat the previous step \\
\hline S7 & Repeat the previous step \\
\hline S8 & Repeat the previous step \\
\hline$\ldots$ & $\ldots$ \\
\hline S14 & Excavate inverted arch \\
\hline S15 & Lay steel for inverted arch \\
\hline S16 & Inverted arch \\
\hline S17 & Second lining \\
\hline
\end{tabular}

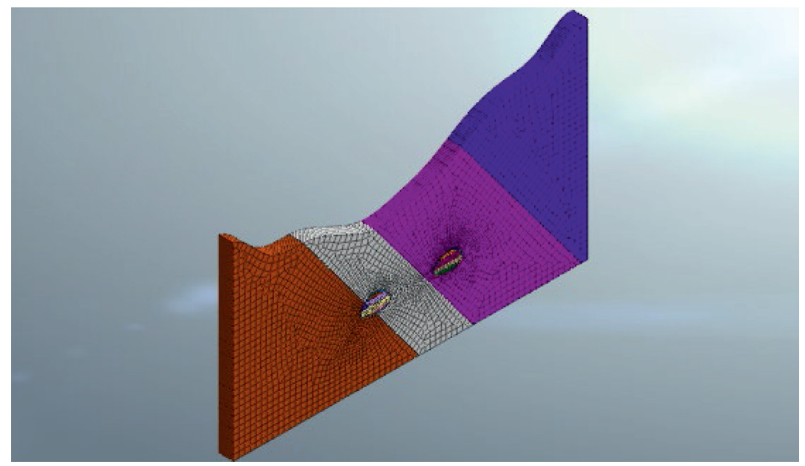

Figure 8: Model of the three-step method.

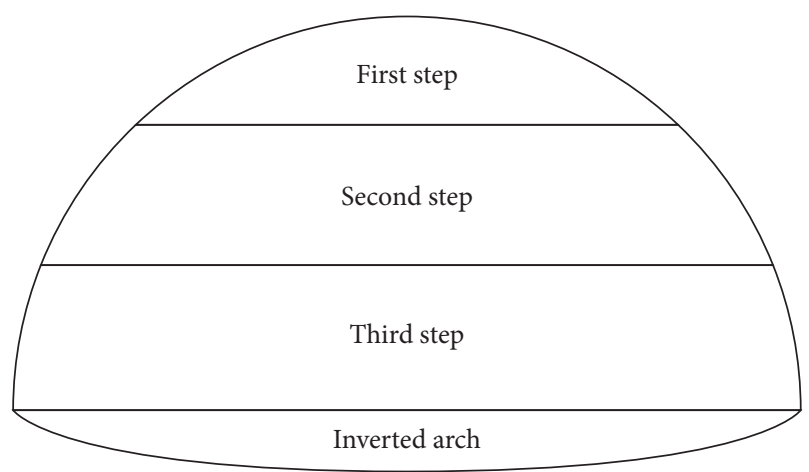

FIgURE 9: Construction sketch of the three-step method.

3.3. Three-Step Dynamic Balance Excavation Method. Calculations for excavation with the three-step construction model were performed. The plastic area, arch displacement, stress distribution of surrounding rocks, initial lining, and second lining are shown in Figures 24-30.

During the three-step construction, the maximum principal stress of tunnel II is $0.41 \mathrm{MPa}$, the maximum principal stresses at the left vault and arch foot are $0.1 \mathrm{MPa}$ and $4.96 \mathrm{MPa}$, and the maximum value of small principal stress is $0.047 \mathrm{MPa}$ at the right vault and $0.027 \mathrm{MPa}$ at the left vault of the tunnel.
When the three-step excavation method is completed, the maximum settlement of the vault of tunnel $\mathrm{I}$ is $21.7 \mathrm{~mm}$ and the maximum uplift of the bottom is $16.7 \mathrm{~mm}$. The maximum settlement of tunnel II is $17.1 \mathrm{~mm}$ and the maximum uplift of the bottom is $11.6 \mathrm{~mm}$.

In three-step method, the horizontal deformation at the left arch foot of tunnel $\mathrm{I}$ is $-3.4 \mathrm{~mm}$ while it is $4.9 \mathrm{~mm}$ at the right arch foot. The horizontal deformation of the surrounding rocks at the left arch foot of tunnel II is about $-2.9 \mathrm{~mm}$ and $3.6 \mathrm{~mm}$ at the right arch foot.

The maximum concentrated stress is $6.4 \mathrm{MPa}$ at the arch foot in three-step method. Due to stress diffusion near the top, the stress of the vault of tunnel II is about $0.4 \mathrm{MPa}$, which appears as compressive stress. However, the stress value is about $0.4 \mathrm{MPa}$ at the vault of tunnel $\mathrm{I}$, which is expressed as tensile stress.

The stress at the top of the second lining of tunnel II is about $0.039 \mathrm{MPa}$, and the arch foot stress is about $0.038 \mathrm{MPa}$. The stress at the top of the second lining of tunnel $\mathrm{I}$ is $0.037 \mathrm{MPa}$, while it is $0.023 \mathrm{MPa}$ at the arch foot.

\subsection{Mechanical Response of Tunnels with Different Construction Methods}

3.4.1. Plastic Zone of Surrounding Rocks. With the excavation and unloading of the tunnel, the surrounding rocks deform, the stress redistributes, and a certain range of plastic area appears. The tunnel vault can be considered as a stretched plastic area and the side wall arch waist as a shear plastic area. For the same excavation method, due to the influence of different geology condition, the plastic zone of tunnel II is smaller than that of tunnel I. The plastic zone mainly distributes in the arch foot of the deep buried bias zone and the arch waist of the shallow-buried zone. The foot of the side wall and the waist of the shallow arch are the weaknesses in the construction of shallow-buried tunnel, which is prone to instability. Relatively speaking, the plastic zone of the three-step method is the largest. Generally, the plastic areas gradually shrink in three-step method, the single-side wall guide pit method, and the double-side wall pit method. 


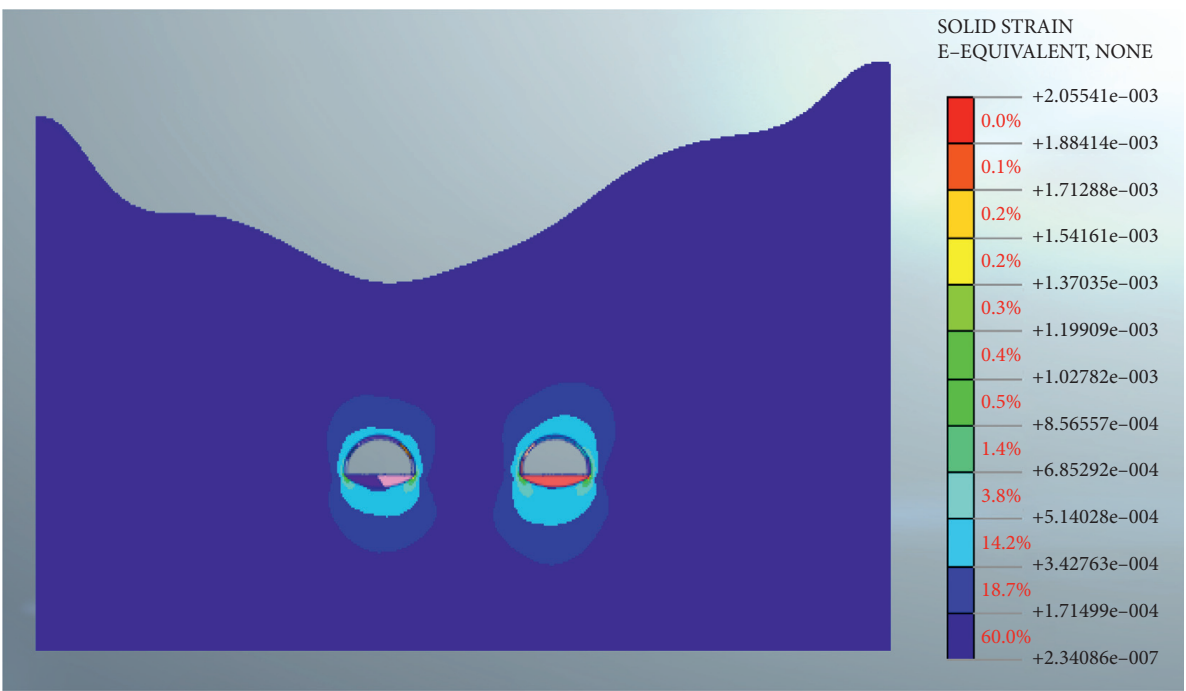

FIgURE 10: Distribution of plastic area in double-side guide pit method.

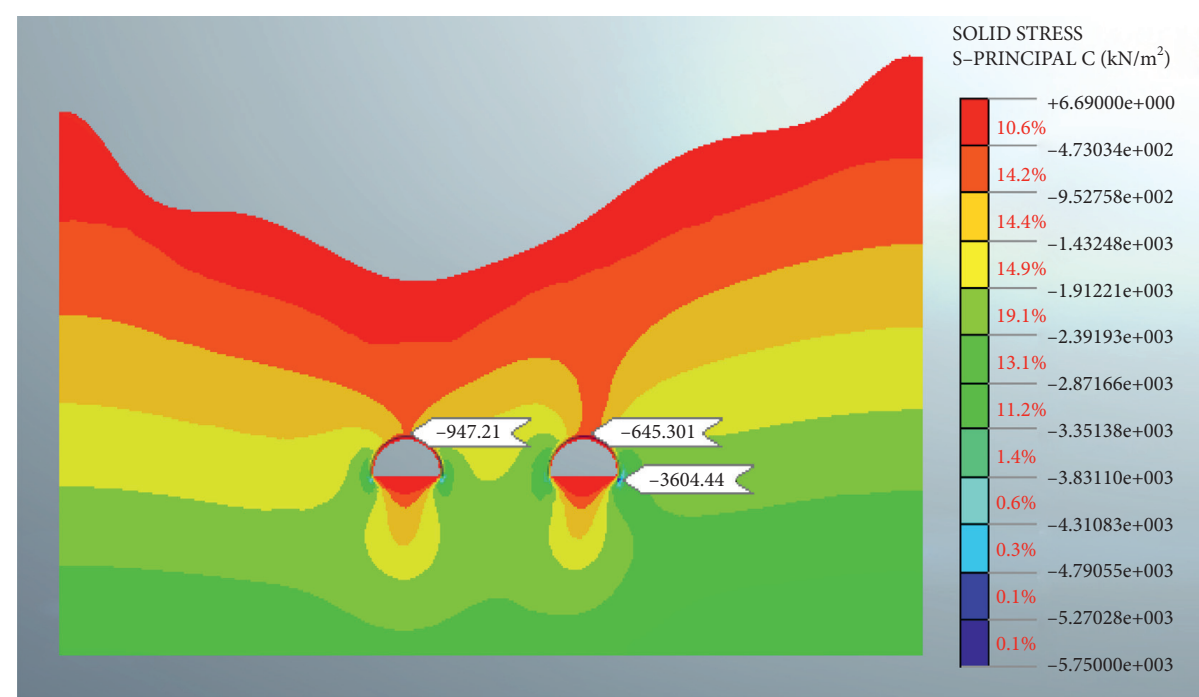

FIGURE 11: Large principal stress distribution of surrounding rocks in double-side guide pit method.

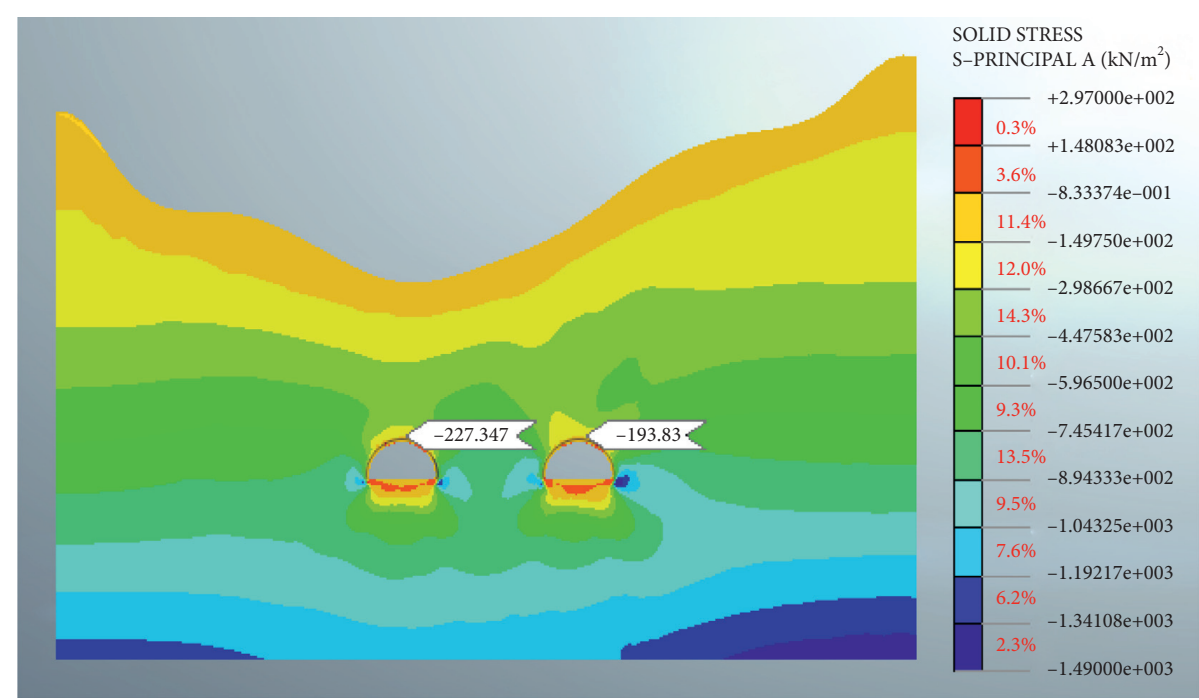

FIGURE 12: Distribution of small principal stresses in surrounding rocks in double-side guide pit method. 


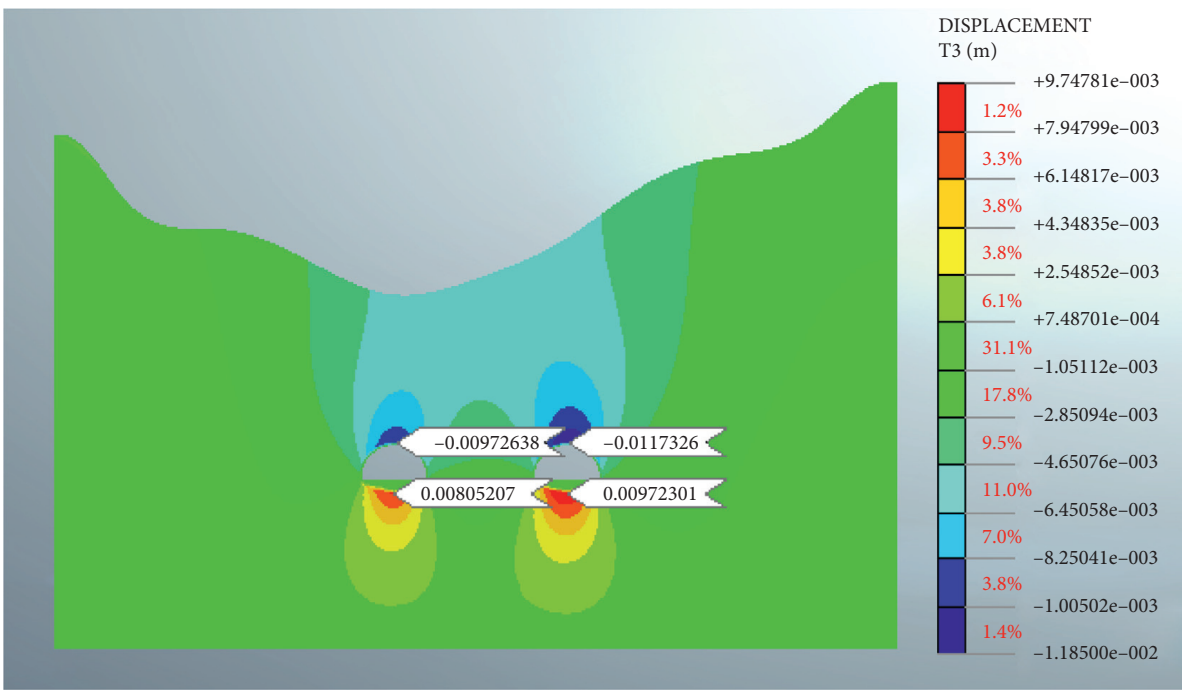

FigURE 13: Vertical displacement distribution of surrounding rocks in double-side guide pit method.

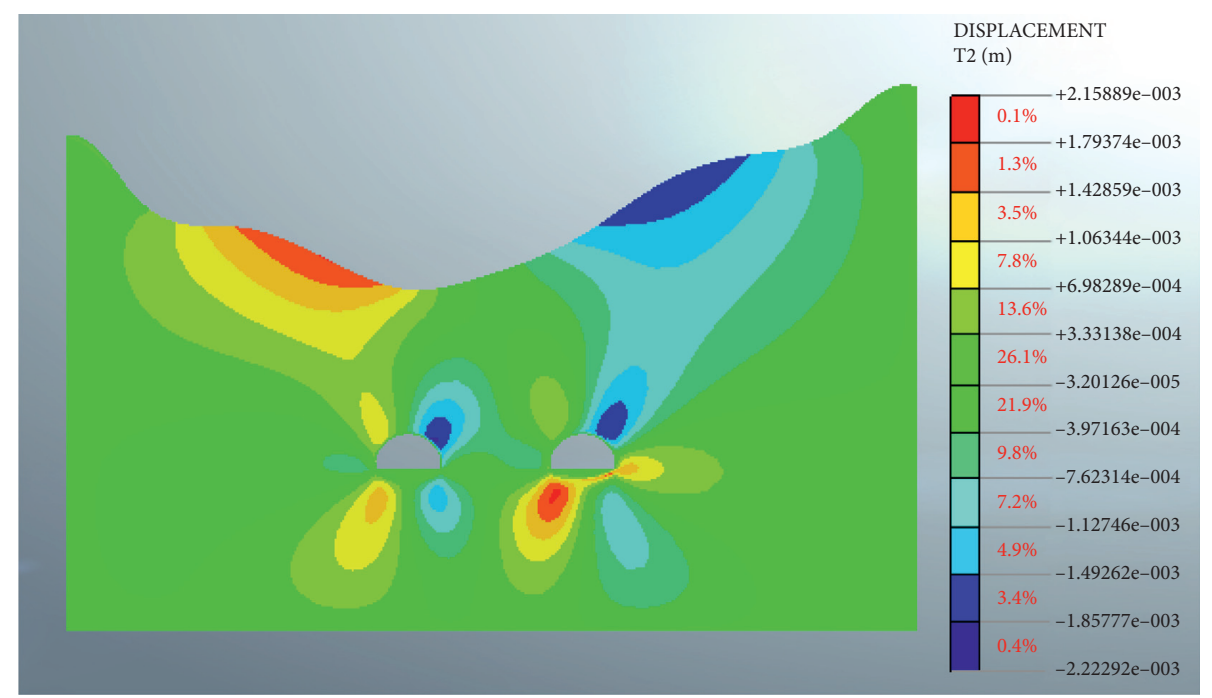

FIGURE 14: Horizontal displacement distribution of surrounding rocks in double-side guide pit method.

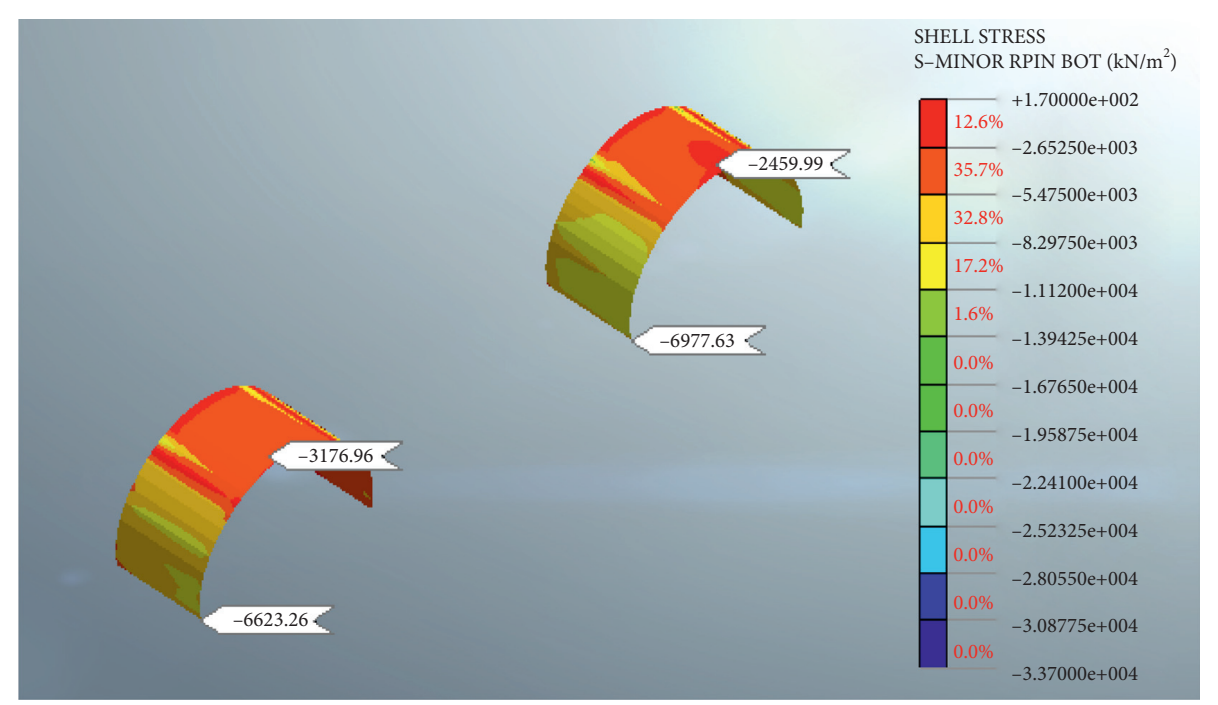

FIGURE 15: Initial lining stress distribution in double-side guide pit method. 


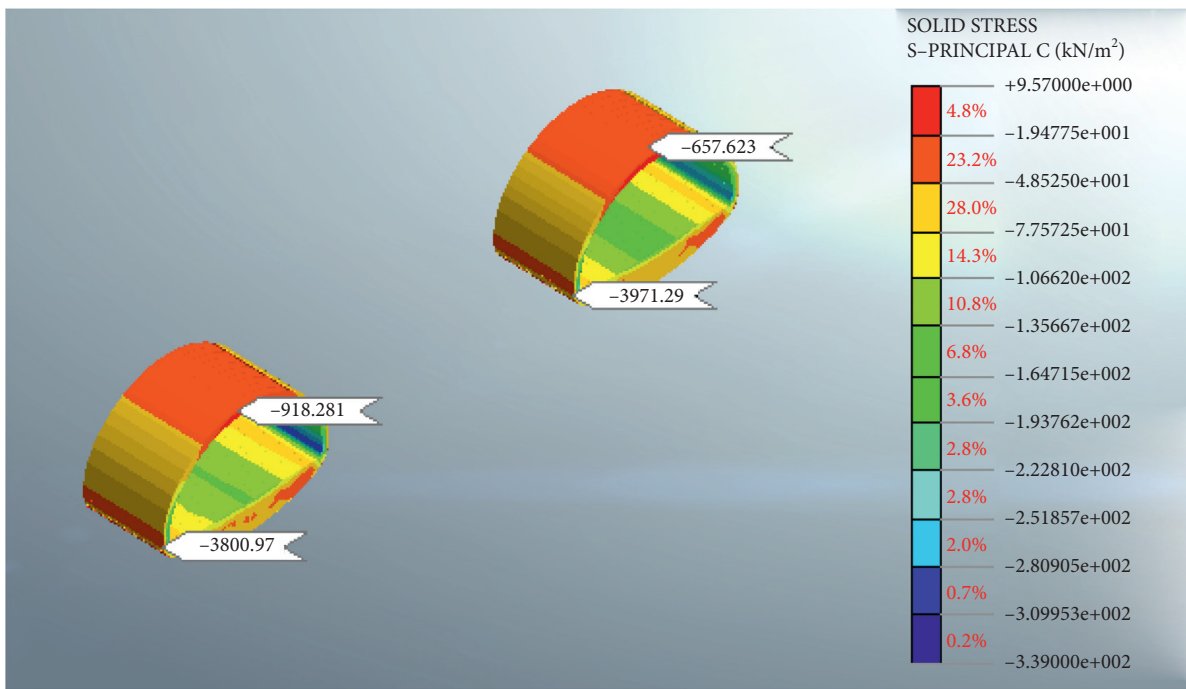

FiguRE 16: Second lining stress distribution in double-side guide pit method.

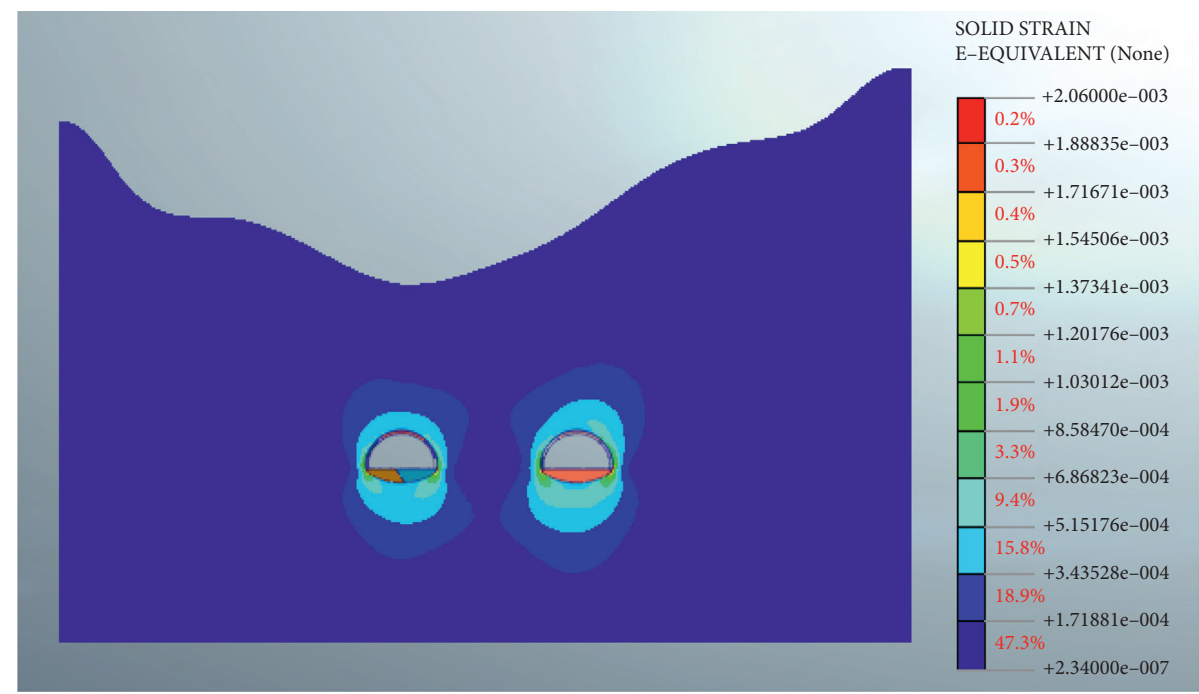

Figure 17: Plastic zone in single-side guide pit method.

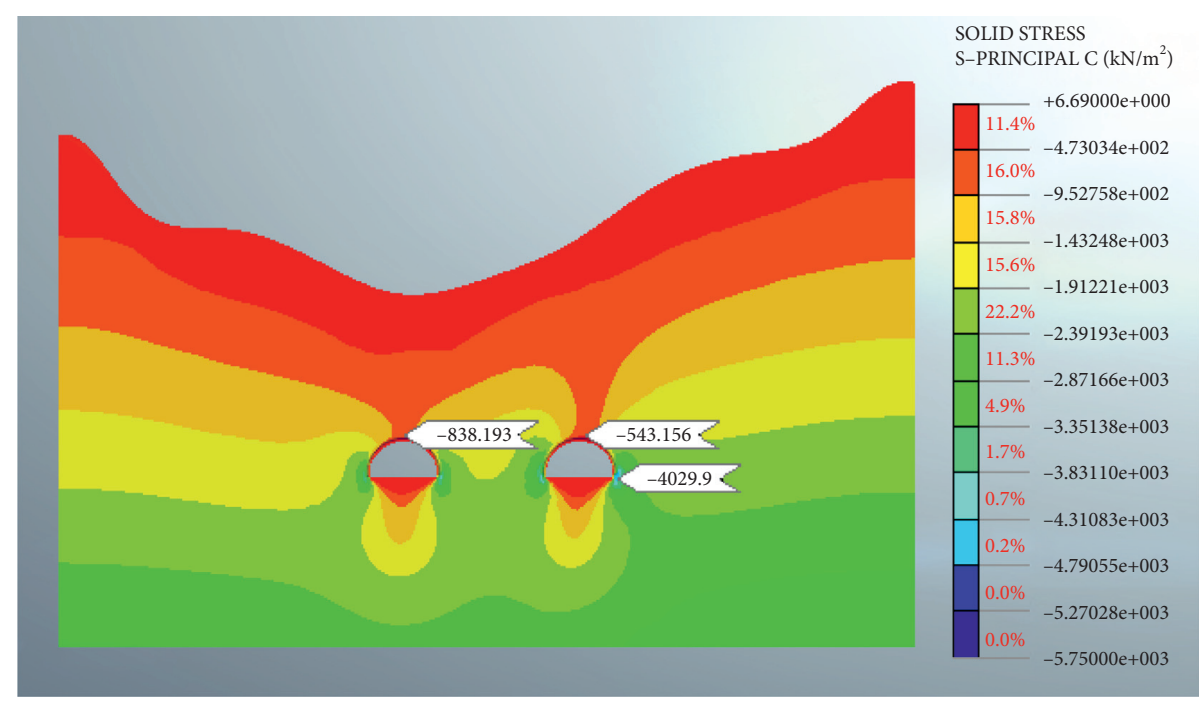

FIGURE 18: Large principal stress distribution of surrounding rocks in single-side guide pit method. 


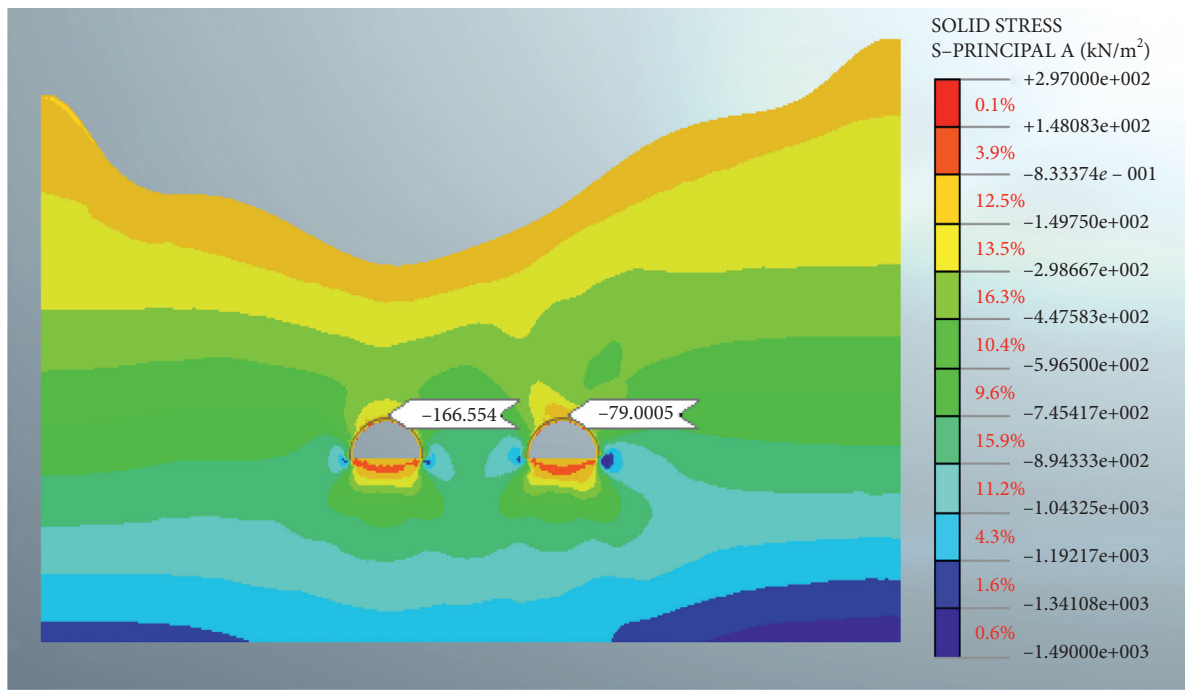

FIGURE 19: Small principal stress distribution of surrounding rocks in single-side guide pit method.

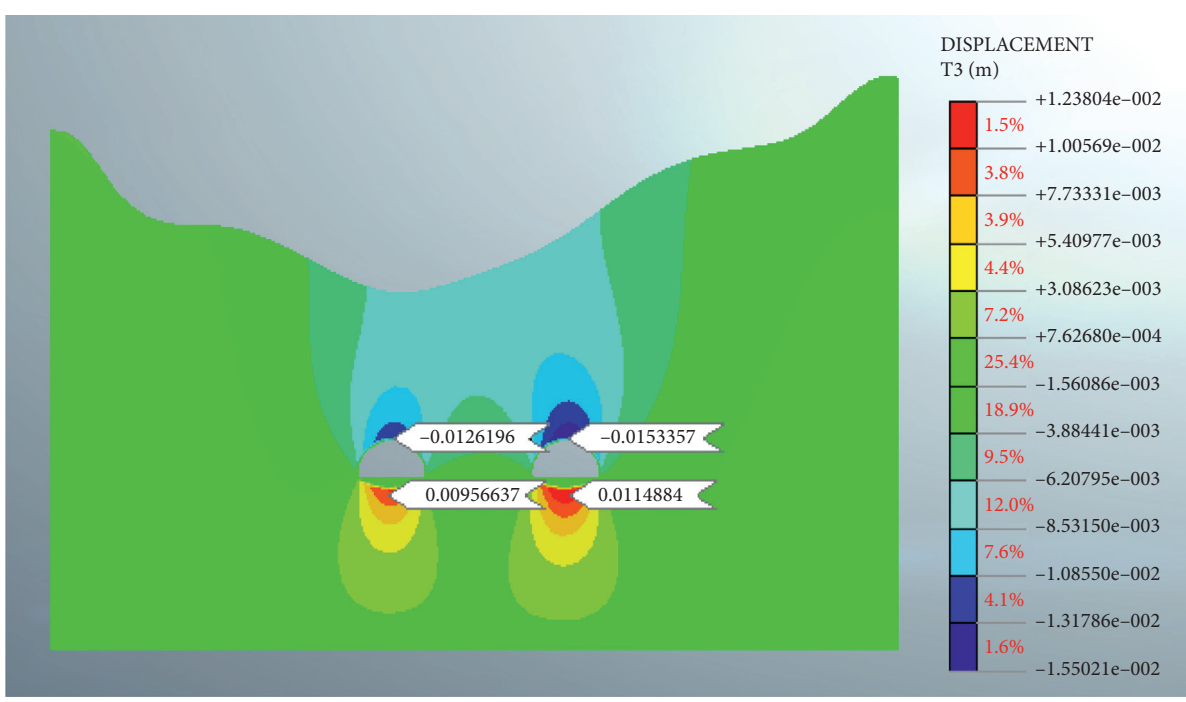

FiguRE 20: Vertical displacement distribution of surrounding rocks by single-side guide pit method.

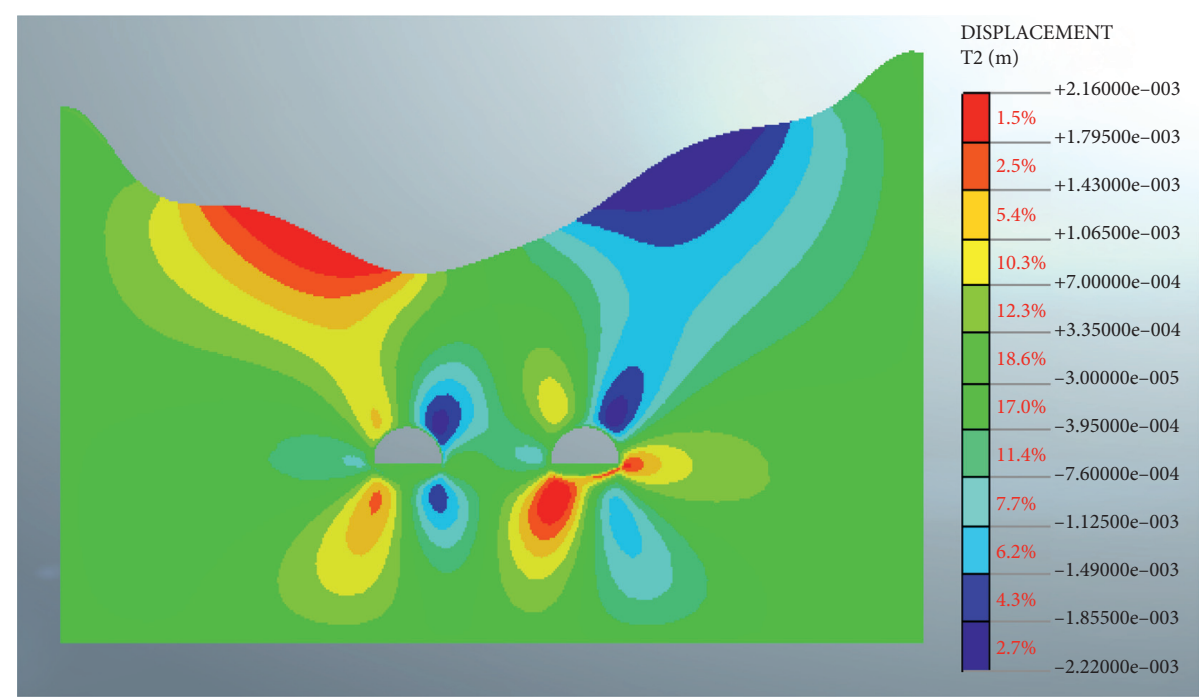

FigURE 21: Horizontal displacement distribution of surrounding rocks by single-side guide pit method. 


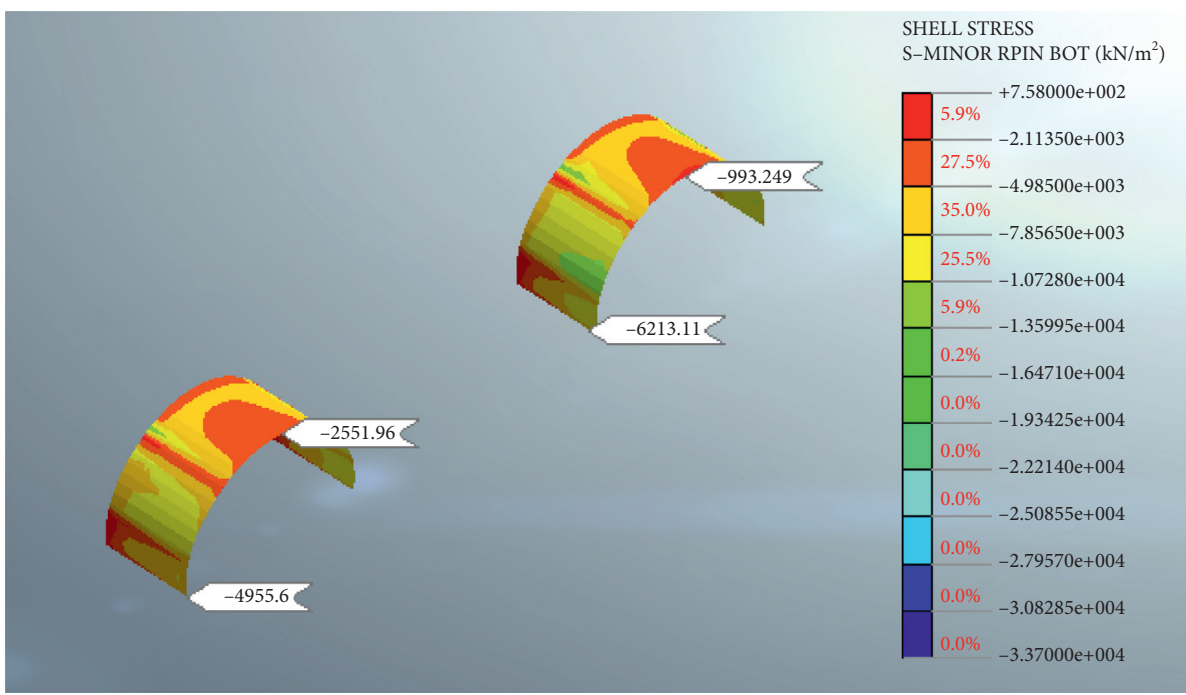

FIgURE 22: Initial lining stress distribution of single-side guide pit method.

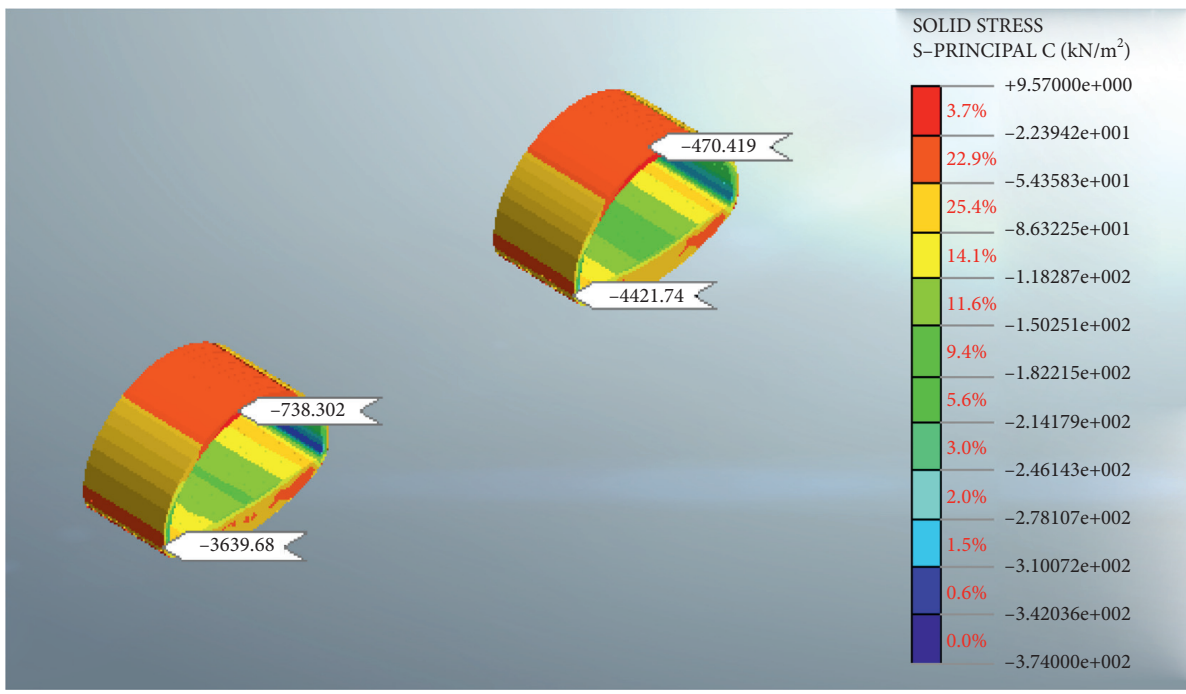

FIGURE 23: Second lining stress distribution of single-side guide pit method.

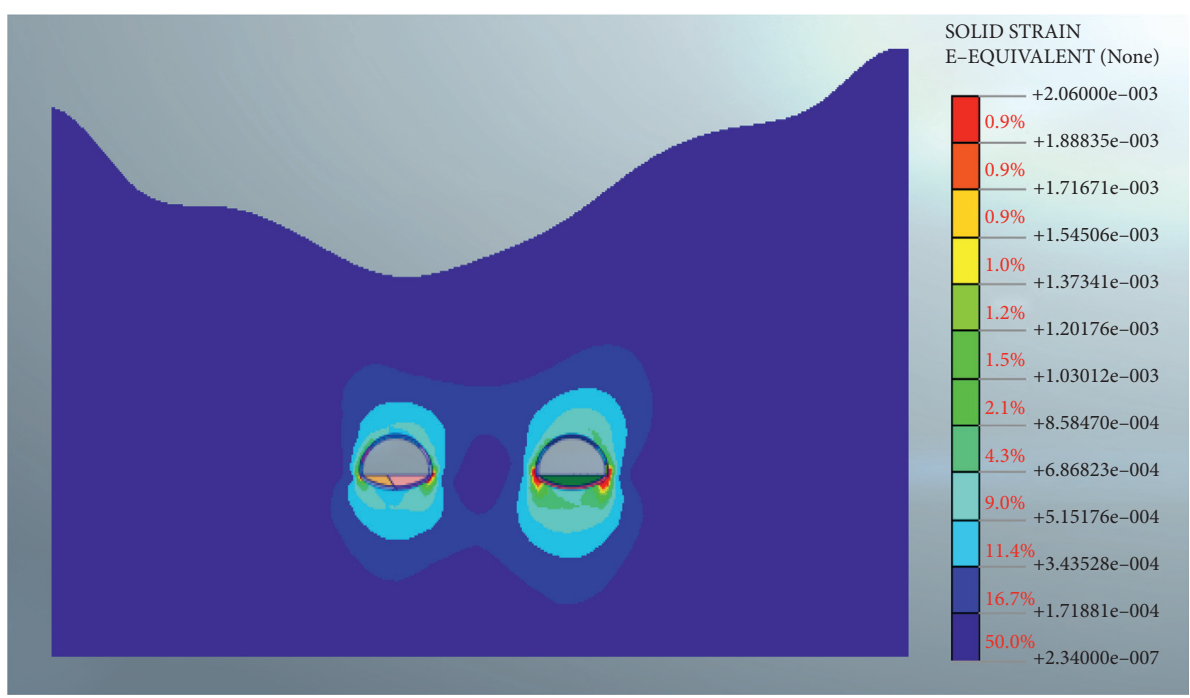

Figure 24: Plastic zone in three-step method. 


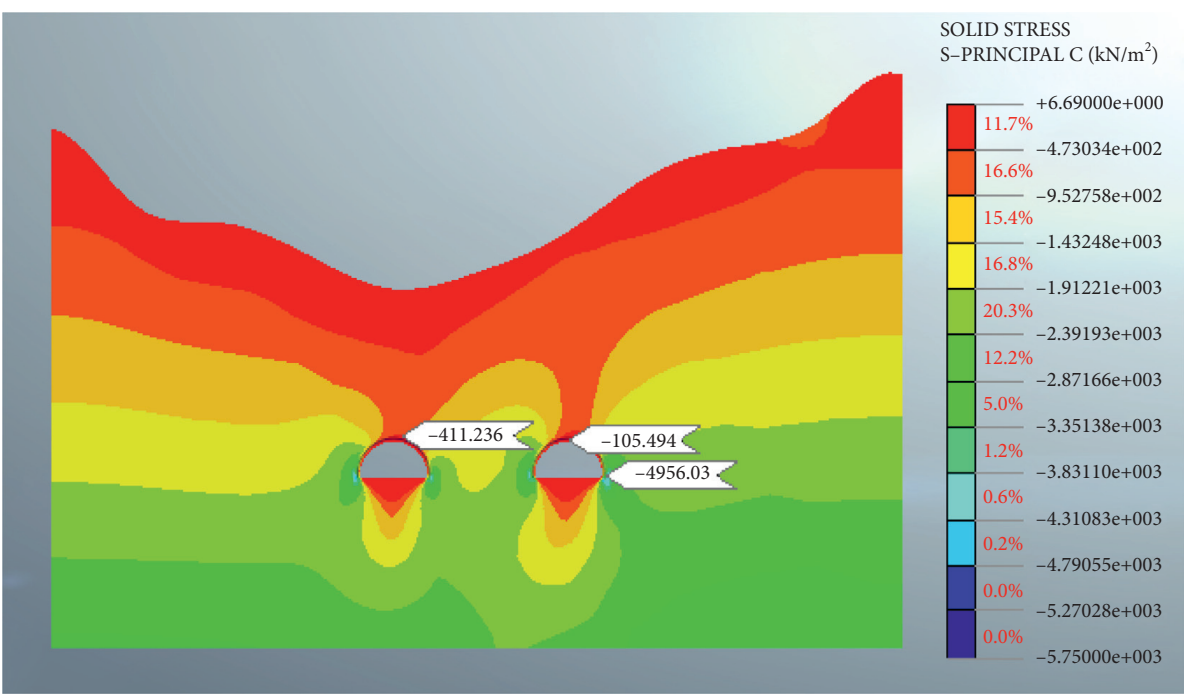

FIGURE 25: Distribution of large principal stresses in surrounding rocks in three-step method.

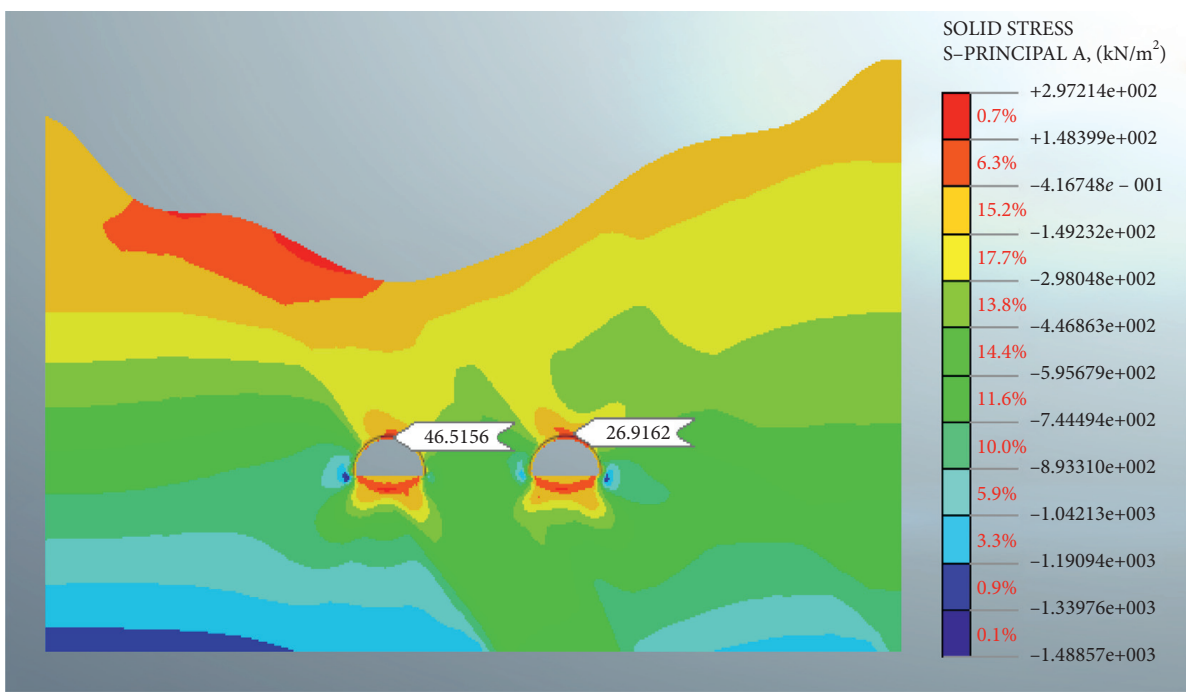

FIGURE 26: Distribution of small principal stress in surrounding rocks in three-step method.

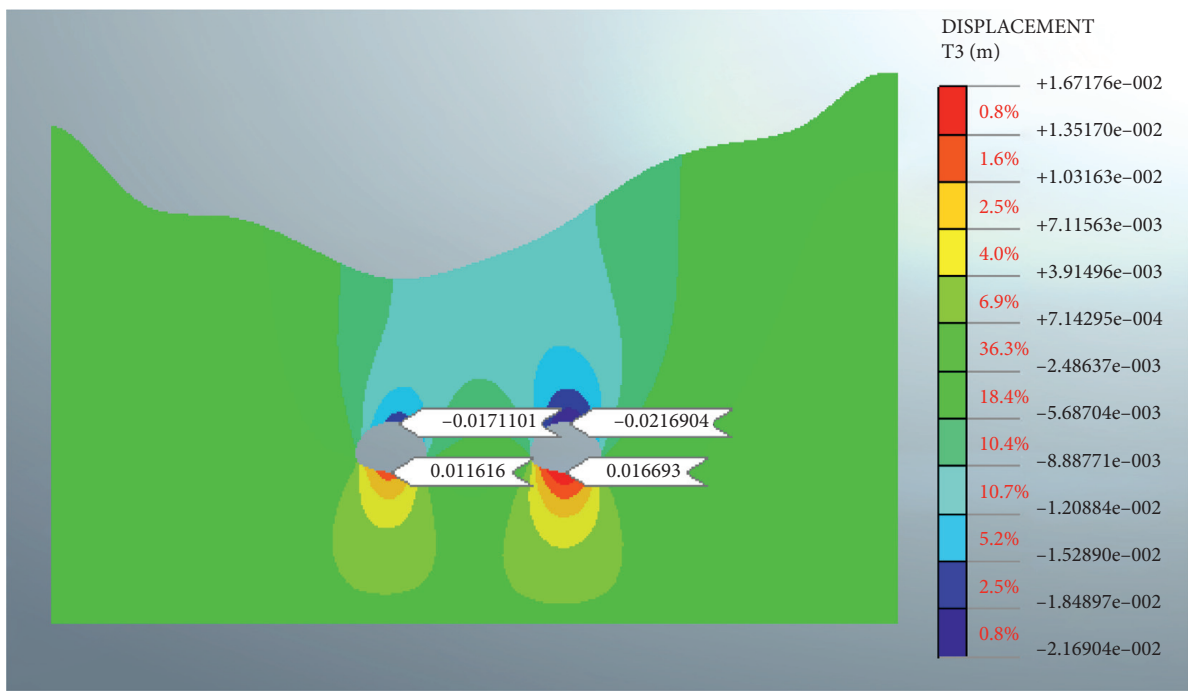

FIGURE 27: Vertical displacement distribution of surrounding rocks by three-step method. 


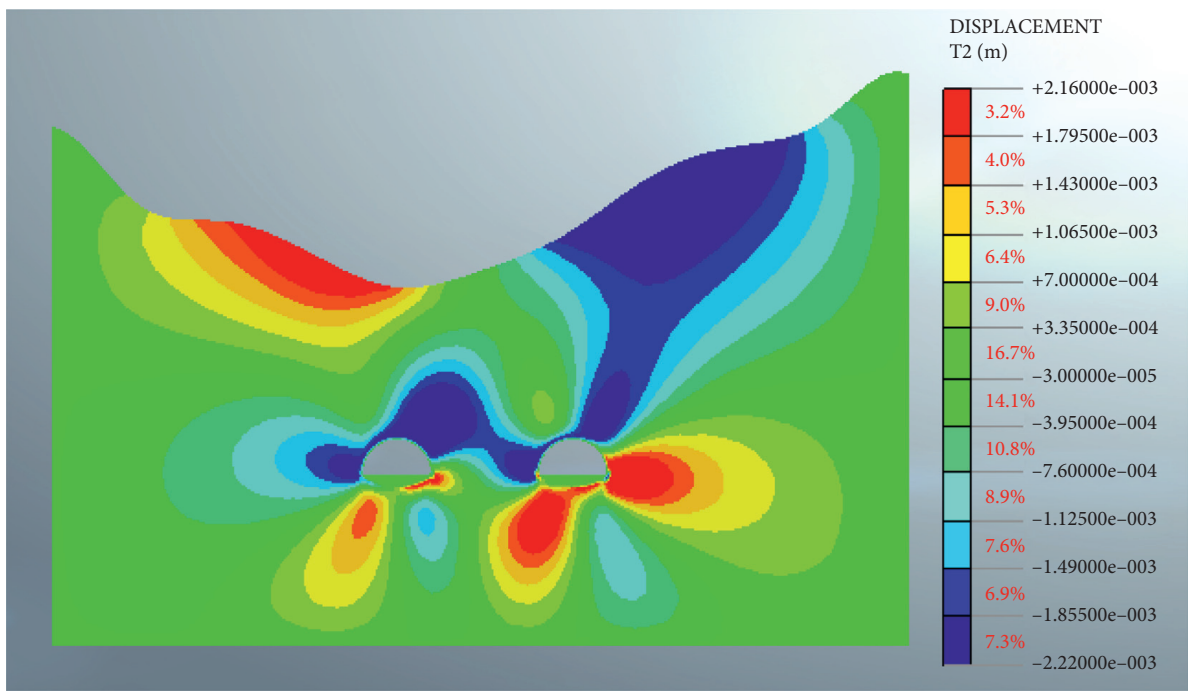

FIgURE 28: Horizontal displacement distribution of surrounding rock by three-step method.

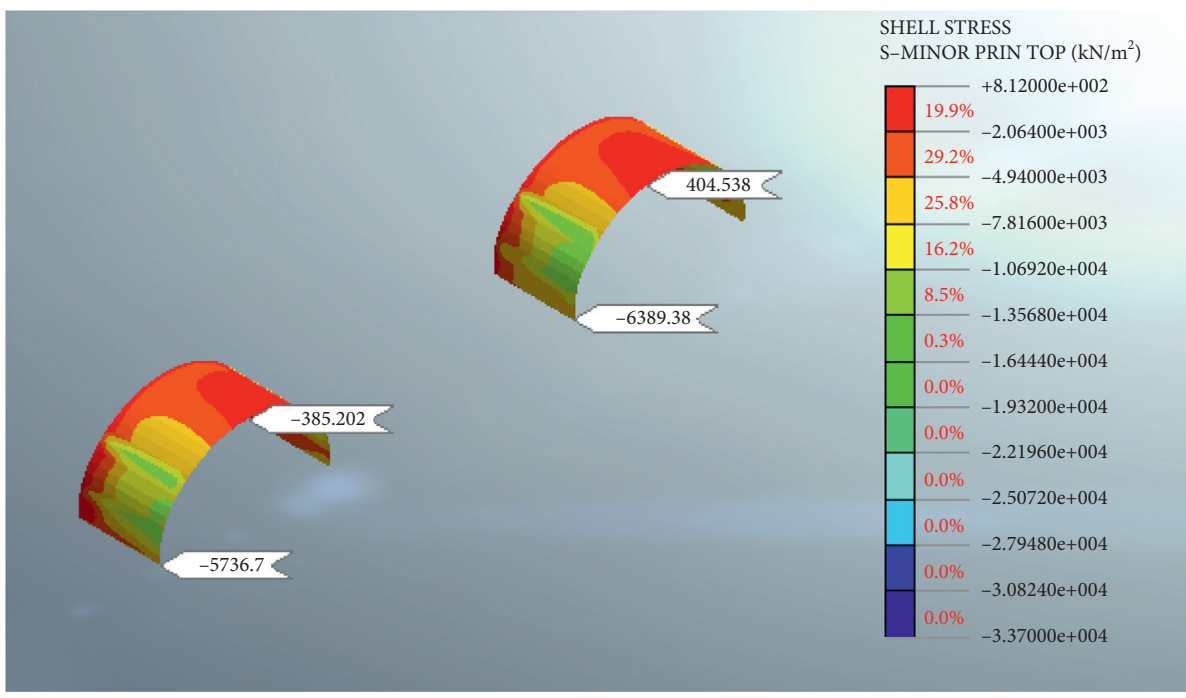

FIGURE 29: Initial lining stress distribution in three-step method.

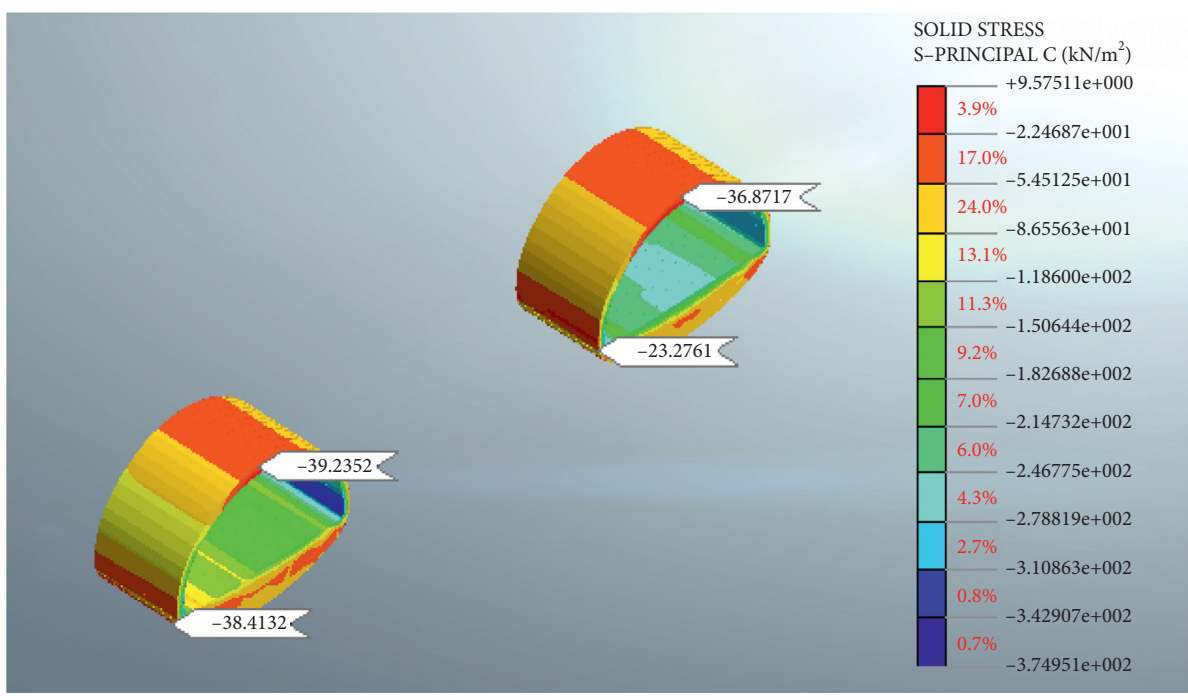

Figure 30: Three-step method of second lining stress distribution. 
3.4.2. Stress of Surrounding Rocks. It is found that the range within about 1 time to the tunnel diameter is the main disturbance zone after excavation. The stress concentration occurs within a certain range of the side wall, with maximum value of about 3.6 to $4.9 \mathrm{MPa}$. The stress concentration in the three-step method is the most obvious, which is $4.9 \mathrm{MPa}$, followed by the single-side wall method, which is $4.0 \mathrm{MPa}$. The double-side wall pit method has the smallest stress concentration of $3.6 \mathrm{MPa}$. However, in the local area of the vault and bottom of the tunnel, the release area and value of stress under the three-step method are significantly larger than those of the single-side wall method and three-step method. The small principal stress under three-step method is $47 \mathrm{kPa}$, which is tensile pressure. The small principal stress under the single-side pit method is the second highest, which is $79 \mathrm{kPa}$ of compressed stress.

Stress release will occur in the local area of the tunnel vault and bottom during the excavation of the tunnel. The stress concentration of the arch foot and the stress release of the arch under the three-step method are more serious than those of the single-side pit guide method and the double-side pit guide method. Although tunnel II is under two different surrounding rock conditions, the different surrounding rock area accounts for a small proportion of the total surrounding rocks. At the same time, the support and lining with greater structural strength during the simulation were carried out. Thus, the difference of surrounding rock conditions has little influence on the stability of the surrounding rocks of tunnel II.

\subsubsection{Vertical Displacement of Surrounding Rocks.} Table 6 shows the vertical displacement of the surrounding rocks under different construction methods.

According to the reserved deformation amount specified in the Design Code for Highway Tunnels (JTGD70-2004), the reserved deformation of tunnel I is $100-150 \mathrm{~mm}$, while it is $80-120 \mathrm{~mm}$ in tunnel II. All the displacement values of simulation meet the specifications.

Figures 31-34 show the displacement of the surrounding rocks during construction.

During the excavation of the tunnel, the gravity and the stress of the surrounding rocks lead to the settlement of the vault. The gravity above the tunnel bottom is relieved, so the upward displacement happens. In three-step method, the first step of excavation is near to the vault, and the displacement of the vault increases rapidly. During the excavation, the exposed area of surrounding rocks becomes larger and larger, which leads to the displacement increase of the top and bottom of the tunnel. After step S6, the surrounding rocks gradually become stabilized and the change of displacement becomes slower. In double-side pilot pit method, the two sides of the tunnel are excavated first, and the displacement of the vault changes slowly. After step S5, the rocks under the tunnel vault are excavated, resulting in a rapid increase in the displacement of the vault. Due to the decrease pressure of rocks above the bottom, the uplift displacement increases instantly and then grows slowly under the effect of the surrounding rocks. In single-side pilot pit method, the two sides of the tunnel are excavated first, and the displacement of the vault changes slowly. When step S3 is completed, most of the rocks under the vault are excavated, resulting in a rapid increase of the displacement until the rocks in the section become stabilized. After step S4, due to the excavation of the rocks above the bottom, the uplift displacement increases instantaneously. When step S6 is completed, the displacement grows slowly.

It can be concluded that the displacement of vault and bottom under the three-step method are larger than those of the single-side and double-side guide pit methods. Overall, the displacement of the surrounding rocks under the threestep method is slightly larger than that under the single-side pit guide method and the double-side pit guide method. However, it also meets the requirement of reserved deformation by the code and can be applied in shallow-buried large-span tunnels.

3.4.4. Horizontal Displacement of Surrounding Rocks. Table 7 shows the horizontal displacement of surrounding rocks under different construction methods.

Due to the bias earth pressure, the horizontal displacements on both sides of the tunnel are asymmetrical. The deformation of surrounding rocks at the top of the threestep guide pit tunnel is large, which causes a large pressure on the supporting structure. Due to the small excavation cross section, both the single-side guide pit method and the double-side guide pit method produce less horizontal displacement and deformation than the three-step method. The stability of the tunnel is closely related to the support timing. Timely support and real-time monitoring will ensure the overall stability of the tunnel.

3.4.5. Stress of Initial Lining. The stress concentration phenomenon occurred near the sidewall of the initial lining structure and the arch foot. The stress diffusion appeared near the top of the arch. The rock stress releases a lot on the support structure due to the large excavation section of the three-step method, and the deformation continues after the initial lining installed. Thus, it is necessary to make the support structures be integrated as soon as possible, so as not to cause excessive deformation of surrounding rocks and damage that would greatly increase the pressure on the initial lining. The single excavation part of the single-side guide pit method is smaller than that of the three-step method, and the surrounding rocks are locally deformed but not damaged. In double-side guide pit excavation method, the surrounding rocks are timely supported and the deformation is small.

3.4.6. Stress of Second Lining. It is known from the simulation that the stress on the second lining under the threestep method is very small. Before the second lining is set up, the surrounding rocks nearly reach stress equilibrium. Due to the small excavation cross sections of the single-side pit guide method and the double-side pit guide method, the overlying surrounding rocks will reach a temporary 
TABLE 6: Vertical displacement of surrounding rocks.

\begin{tabular}{lcccc}
\hline Method & $\begin{array}{c}\text { Vault settlement } \\
\text { of tunnel I }(\mathrm{mm})\end{array}$ & $\begin{array}{c}\text { Bottom uplift of } \\
\text { tunnel I (mm) }\end{array}$ & $\begin{array}{c}\text { Vault settlement of } \\
\text { tunnel II (mm) }\end{array}$ & $\begin{array}{c}\text { Bottom uplift of } \\
\text { tunnel II (mm) }\end{array}$ \\
\hline Three-step method & 21.7 & 16.7 & 17.1 & 11.6 \\
Single-side guide pit method & 15.3 & 11.5 & 12.6 & 9.6 \\
Double-side guide pit method & 11.7 & 9.7 & 9.7 & 8.1 \\
\hline
\end{tabular}

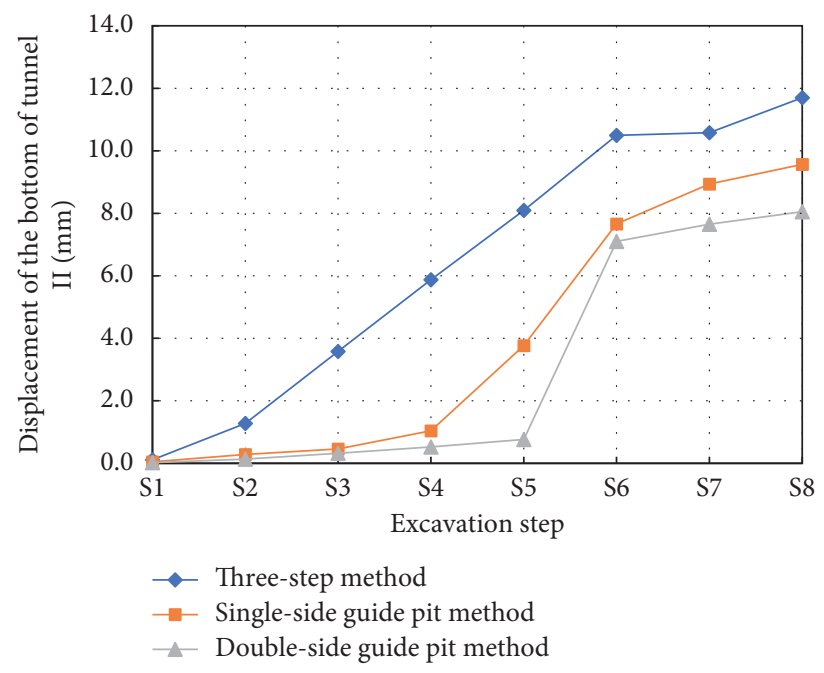

FIgURE 31: Displacement of the bottom of tunnel II.

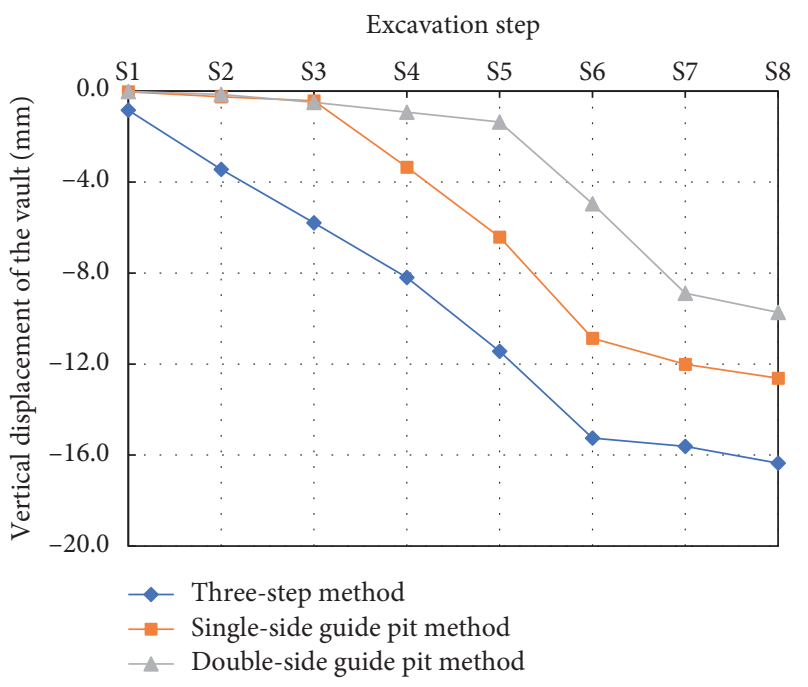

FIGURE 32: Displacement of the vault of tunnel II.

equilibrium state with a small displacement under the support of the initial lining and temporary support. When the support is removed, it will take a certain amount of time for the surrounding rocks and the initial lining to reach equilibrium again. The second lining has been completed and the stress reaches a new equilibrium state under the combined action of the surrounding rocks, initial lining, and second lining. In this case, the second lining bears only part of the overlying load, and the second lining is subject to a little bit larger stress in the single-side guide pit method and the double-side guide pit method.

\section{In Situ Monitoring}

It is obtained from the above results that the three methods are all rationality. However, from the view of construction time and economy, the construction method of three steps is more simple, fast, and economical. Although the 


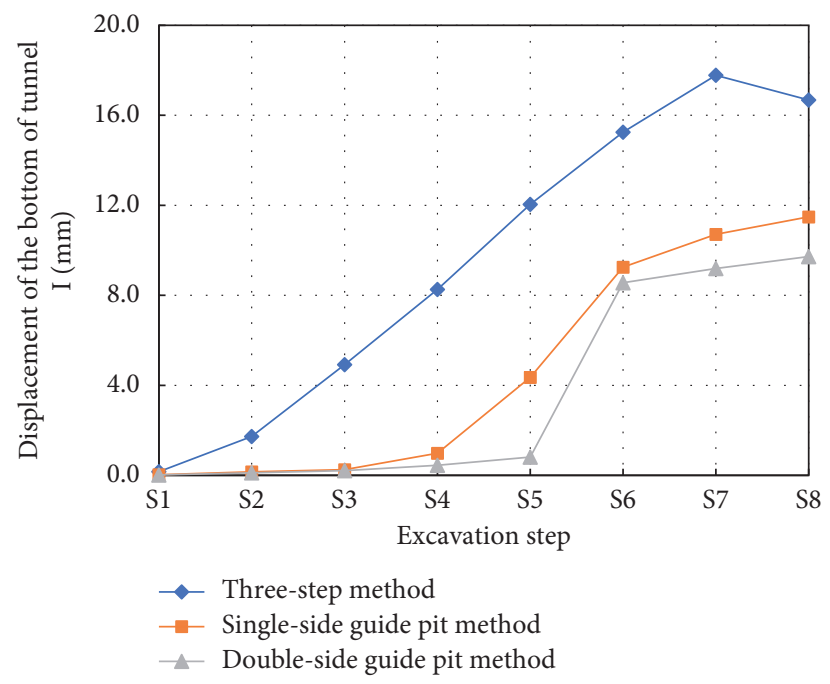

Figure 33: Displacement of the bottom of tunnel I.

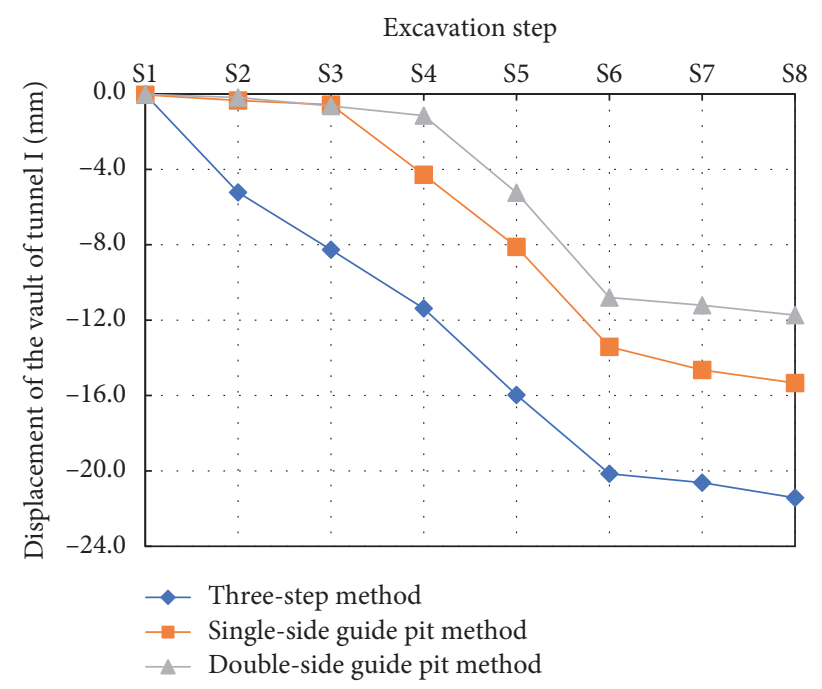

FIGURE 34: Displacement of the vault of tunnel I.

TABle 7: Horizontal displacement of surrounding rocks.

\begin{tabular}{lcccc}
\hline Method & $\begin{array}{c}\text { Left arch foot of } \\
\text { tunnel I }(\mathrm{mm})\end{array}$ & $\begin{array}{c}\text { Right arch foot } \\
\text { of tunnel II (mm) }\end{array}$ & $\begin{array}{c}\text { Left arch foot } \\
\text { of tunnel II (mm) }\end{array}$ & $\begin{array}{c}\text { Right arch foot } \\
\text { of tunnel II (mm) }\end{array}$ \\
\hline Three-step method & -3.4 & 4.9 & -2.9 & 3.6 \\
Single-side guide pit method & -1.5 & 2.4 & -0.9 & -1.1 \\
Double-side guide pit method & -0.8 & 1.1 & -0.4 & -0.8 \\
\hline
\end{tabular}

deformation and stress of surrounding rocks are larger than the other two methods, it still meets the requirements.

The main monitoring content is the pressure between the surrounding rocks and the initial lining. Soil pressure sensors were arranged on the contact surface of the surrounding rocks and the initial lining, to study the change law of surrounding rock pressure in the entire construction process. The soil pressure sensors are shown in Figure 35. The locations are shown in Figure 36 and the data of monitoring is shown in Figure 37.
According to Figure 37, it is found that the contact pressure between the surrounding rocks and the lining fluctuates during the entire construction process. However, as the excavation face moves away from the monitoring section, the stress of surrounding rocks gradually becomes stabilized. Due to the influence of bias pressure on the left side of the tunnel, the value of the monitoring point on the left is greater than that on the right side. The force of point T2-1 is the greatest. The horizontal pressure on the left side fluctuates greatly during the construction process, indicating 


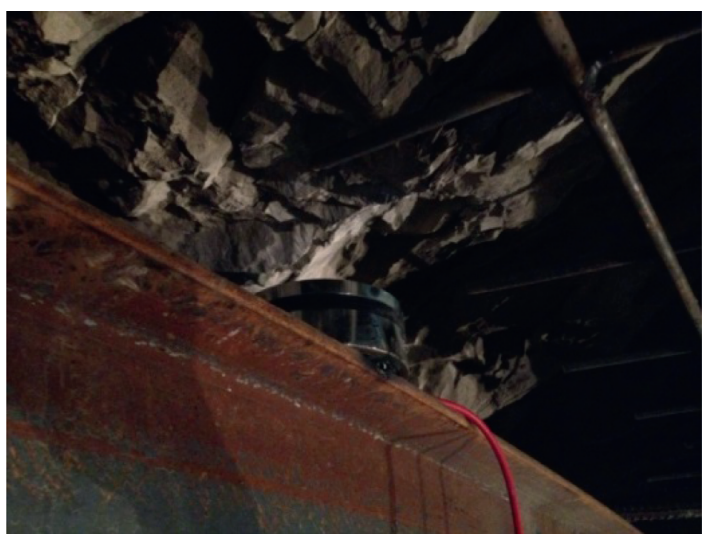

FIGURE 35: Installation diagram of soil pressure sensors.

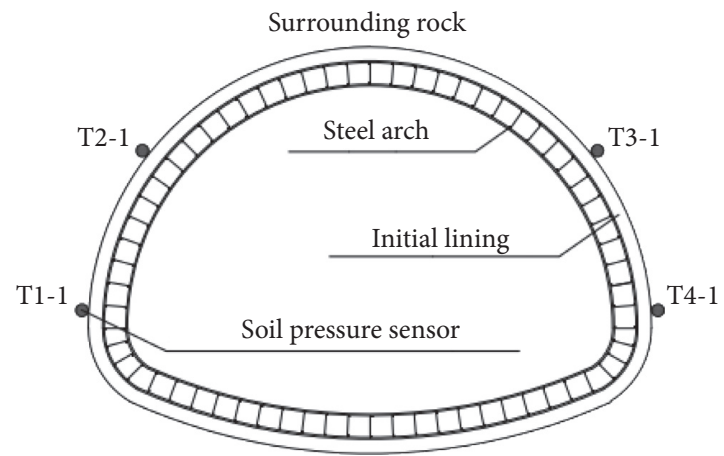

FiguRE 36: Location of soil pressure sensors.

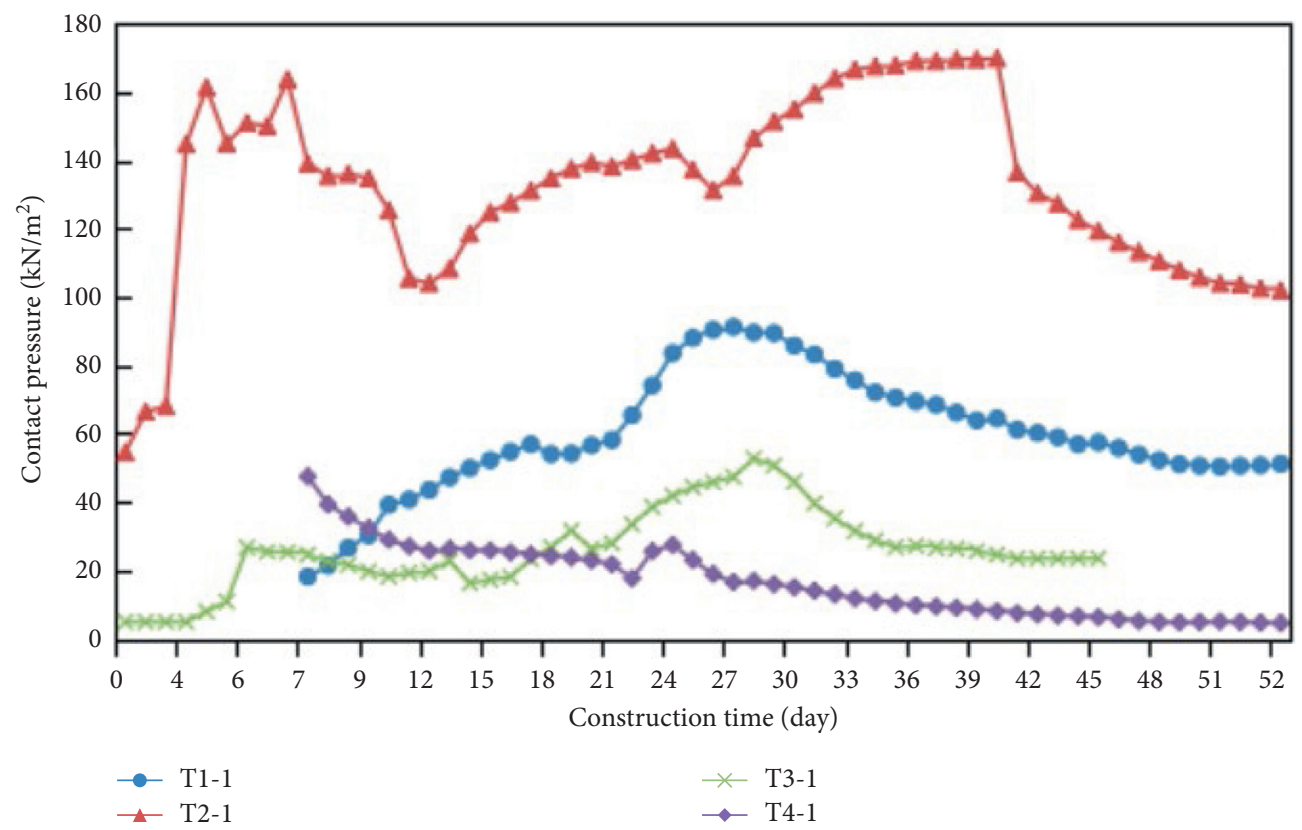

FIGURE 37: Contact pressures between surrounding rocks and primary lining.

that the surrounding rocks at the left arch waist are more unstable than other locations in the tunnel under the same support method. The force of surrounding rocks at point
T2-1 fluctuates greatly due to the impact of the tunnel excavation, blasting, and mechanical construction. Finally, the pressure at the left arch waist is approximately $100 \mathrm{kPa}$, 
while the pressure at the right arch waist is approximately $30 \mathrm{kPa}$. The pressure at the left arch foot is approximately $50 \mathrm{kPa}$ and the pressure at the right arch foot is approximately $5 \mathrm{kPa}$, which indicates that the bias pressure has a significant influence on the pressure of the surrounding rocks.

The actual construction is carried out with the optimal construction parameters obtained through simulation and the parameters are monitored. The results of the stress and displacement also meet the requirements of safety and efficiency and are economic. It shows that the dynamic balance excavation of the three-step method is suitable for the tunneling under the condition of being shallow-buried large-span.

\section{Conclusions}

(1) The double-side, single-side, and three-step construction processes are simulated and studied based on the tunnel of Qichongcun. The distribution of stress, displacement of surrounding rocks, and initial and secondary linings were studied. The research results show that the mechanical response of the surrounding rocks and supporting structures are greatly affected by the excavation methods.

(2) Through comparative research, it is found that the displacement and stress of the three-step dynamic balance excavation method are larger than those of the other two methods, but it still meets the requirements of support safety.

(3) The three-step excavation method is implemented on site and the control parameters were monitored. The results show that the three-step dynamic balance excavation method can be applied in shallow-buried large-span karst tunnels under the similar geological conditions.

\section{Data Availability}

The data used to support the findings of this study are included within the article.

\section{Conflicts of Interest}

The authors declare that they have no conflicts of interest.

\section{Acknowledgments}

The authors were supported by the National Natural Science Foundation of China (Grant no. 41807230) and Fundamental Research Funds for the Central Universities (Grant no. 2-9-2018-090).

\section{References}

[1] B. Wang, "Analysis on the law of karst development in Lianhuashan tunnel," Highways, vol. 8, pp. 226-230, 2019, in Chinese.

[2] J. Li and L. Fu, "Discussion on treatment technology of tunnel caverns in Karst Karst areas in Guangxi," Western China
Communications Science \& Technology, vol. 11, pp. 74-77, 2019, in Chinese.

[3] S. Li, K. Wang, L. Li, Z. Zhou, S. Shi, and S. Liu, "The formation mechanism and development trend of water inrush disaster in karst tunnel," Chinese Journal of Theoretical and Applied Mechanics, vol. 49, no. 1, pp. 22-30, 2017.

[4] F. Wang, Y. Zhao, C. Li et al., "An experimental study on the corrosion characteristics of the karst tunnel engineering area in Southwest China," Bulletin of Engineering Geology and the Environment, vol. 78, no. 6, pp. 4047-4061, 2019.

[5] H. Fan, Y. Zhang, S. He, K. Wang, X. Wang, and H. Wang, "Hazards and treatment of karst tunneling in Qinling-Daba mountainous area: overview and lessons learnt from Yichang-Wanzhou railway system," Environmental Earth Sciences, vol. 77, no. 19, pp. 1-18, 2018.

[6] S. Alija, F. J. Torrijo, and M. Quinta-Ferreira, "Geological engineering problems associated with tunnel construction in karst rock masses: the case of Gavarres tunnel (Spain)," Engineering Geology, vol. 157, pp. 103-111, 2013.

[7] C. Lin, M. Zhang, Z. Zhou et al., "A new quantitative method for risk assessment of water inrush in karst tunnels based on variable weight function and improved cloud model," Tunnelling and Underground Space Technology, vol. 95, Article ID 103136, 2020.

[8] D. Zhao, H. Fan, L. Jia, and Y. Song, "Research on waterproofing and drainage optimization scheme for karst tunnel lining in water-rich areas," Environmental Earth Sciences, vol. 80, no. 4, p. 150, 2021.

[9] S. Shaoshuai, B. Lin, L. Shucai et al., "Application of comprehensive prediction method of water inrush hazards induced by unfavourable geological body in high risk karst tunnel: a case study," Geomatics, Natural Hazards and Risk, vol. 8, no. 2, pp. 1407-1423, 2017.

[10] J. Gao and X. Lin, "Application of advanced geological prediction technology based on three-dimensional detection in dynamic information construction of railway tunnel," Science and Technology, vol. 21, p. 41, 2018, in Chinese.

[11] L. A. Gallardo and M. A. Meju, "Joint two-dimensional crossgradient imaging of magnetotelluric and seismic traveltime data for structural and lithological classification," Geophysical Journal International, vol. 169, no. 3, pp. 1261-1272, 2007.

[12] M. A. Meju, L. A. Gallardo, and A. K. Mohamed, "Evidence for correlation of electrical resistivity and seismic velocity in heterogeneous near-surface materials," Geophysical Research Letters, vol. 30, no. 7, p. 26, 2003.

[13] H. Xin, L. Shucai, and X. Zhen-Hao, "An attribute recognition model for safe thickness assessment between concealed karst cave and tunnel," Journal of Central South University, vol. 26, no. 4, pp. 955-969, 2019.

[14] Q. Shengwu, M. Zhongjun, J. Chuandong et al., "Application of magnetic resonance sounding to tunnels for advanced detection of water-related disasters: a case study in the Dadushan tunnel, Guizhou, China," Tunnelling and Underground Space Technology, vol. 84, pp. 364-372, 2019.

[15] V. V. Nazimko, S. S. Peng, A. A. Lapteev, S. N. Alexandrov, and V. P. Sazhnev, "Damage mechanics around a tunnel due to incremental ground pressure," International Journal of Rock Mechanics and Mining Sciences, vol. 34, no. 3-4, pp. 222e1-222e14, 1997.

[16] W. Liu, J. Chen, Y. Luo, L. Chen, Z. Shi, and Y. Wu, "Deformation behaviors and mechanical mechanisms of double primary linings for large-span tunnels in squeezing rock: a case study," Rock Mechanics and Rock Engineering, vol. 54, no. 5, pp. 2291-2310, 2021. 
[17] Z. Chen, C. He, G. Xu, G. Ma, and W. Yang, "Supporting mechanism and mechanical behavior of a double primary support method for tunnels in broken phyllite under high geo-stress: a case study," Bulletin of Engineering Geology and the Environment, vol. 78, no. 7, pp. 5253-5267, 2019.

[18] Z. Chen, C. He, G. Xu, G. Ma, and D. Wu, "A case study on the asymmetric deformation characteristics and mechanical behavior of deep-buried tunnel in phyllite," Rock Mechanics and Rock Engineering, vol. 52, no. 11, pp. 4527-4545, 2019.

[19] J. Lu, Y. Yu, and X. Wang, "Research on mechanical characteristic of weak surrounding rock large span double and multi-arch tunnel construction," The Open Civil Engineering Journal, vol. 8, no. 1, pp. 420-426, 2014.

[20] Q. Hu and Y. Zhou, "Study on the influence of topography on mechanics effect of tunnels," in Proceedings of the, 2011 International Conference on Electrical and Control Engineering (ICECE), Yichang, China, September 2011.

[21] C. Carranza-Torres, "Analytical and numerical study of the mechanics of rockbolt reinforcement around tunnels in rock masses," Rock Mechanics and Rock Engineering, vol. 42, no. 2, pp. 175-228, 2009.

[22] A. Toshihisa, K. Makoto, and K. Kiyoshi, "Experimental study on the distribution of earth pressure and surface settlement through three-dimensional trapdoor tests," Tunelling and Underground SpaceTechnology, vol. 18, no. 5, pp. 171-183, 2003.

[23] D. Sterpi and A. Cividini, "A physical and numerical investigation on the stability of shallow tunnels in strain softening media," Rock Mechanics and Rock Engineering, vol. 37, no. 4, pp. 277-298, 2004.

[24] X. Bian, F. Chen, F. Su, and S. Sun, "Analysis of the mechanical properties of surrounding rock of deep-buried tunnels in karst area," China Railway Science, vol. 34, no. 1, pp. 43-49, 2013, in Chinese.

[25] H. Gu, Study on Mechanical Properties of Surrounding Rock of Tunnel Passing through a Huge Filling Cavern, Southwest Jiaotong University, Sichuan, China, 2019, in Chinese.

[26] G. Wang, Analysis of Stability and Construction Mechanical Behavior of Karst Tunnel Surrounding Rock, Chongqing University, Chongqing, China, 2011, in Chinese.

[27] L. Li, C. Shang, K. Chu et al., "Large-scale geo-mechanical model tests for stability assessment of super-large crosssection tunnel," Tunnelling and Underground Space Technology, vol. 109, Article ID 103756, 2021. 